\title{
The new "windscapes" in the time of energy transition: a comparison of ten European countries
}

\author{
Mauro Giovanni \\ Department of Humanities - University of Trieste
}

\begin{abstract}
The remarkable growth of wind energy in the last twenty years has been accompanied by a rapid spread of wind turbines (WTs) in many European countries, sometimes creating new landscapes that we are supposed to call "windscapes". This paper aims to map the EU regions characterized by a very high density of WTs in those ten EU countries, which for various reasons have become key players in the wind energy sector in Europe. We use the crowdsourced data from a participative mapping project, the OpenStreetMap (OSM), created in 2004 in order to build and share online a free editable map of the world. First, we automatically extract the geographical position of each WT, thus creating a GIS of WTs for each of the EU countries under examination. Having certified the reliability of OSM data, we have to estimate the concentration of WTs. For this reason, we assume that the search radius around each windmill corresponds to its visual impact threshold (roughly equal to $10 \mathrm{~km}$ ). Applying the 'point density' function in a GIS environment, we create the map density of WTs in the study area. In order to have a clear visualization of the impact of the wind energy policies adopted by each EU member state, this map is then compared with the map of wind resources created in 1989. What emerges are two very different situations in the study area: while in the north, Germany and Denmark have seen a massive spread of WTs all over their countries, WTs in the south are mainly concentrated in only a few windy areas of Spain, Portugal and Italy. Moreover, almost $1,350 \mathrm{Km}^{2}$ of land distributed in four member states (Germany, Italy, Spain and United Kingdom) can be said to be characterized by a very high density of WTs (over than 200 WTs in a circle area with a radius of $10 \mathrm{Km}$ ).
\end{abstract}

Keywords: Wind landscapes, OpenStreetMap, Visual impact, Density of wind turbines

\section{Introduction}

In a world still heavily dependent on fossil-based fuel sources, the recent rapid growth in renewables has brought with it significant changes both in the landscape and in society in general. Twenty years after Kyoto, the transition to a new, more sustainable age of energy use is beginning to become a reality. The European Union (EU) has always been a world leader in the field of renewable energy sources (RES) and many of its member states nations are today among the largest producers of sustainable energy. However, the widespread utilization of biomass, wind and solar can have profound effects on the landscape involved. Nadai and van der Horst (2010) talk about a new kind of landscape, called the "landscapes of energies", and point out that «looking at the energy transition through the lens of landscape might contribute in pushing this agenda farther and deepen the analysis of renewable energy policies». Could those regions with a high concentration of onshore wind farms be considered as having a sort of new energy landscape? Given the remarkable number of wind turbines (WTs) spinning around the world by the end of 2016 (about 341,320; Sawyer et al., 2018) which are mainly concentrated in a small number of countries ${ }^{1}$ or rather, in limited areas within these countries, is it reasonable to call these landscapes modern "windscapes"?

In recent decades, wind energy has become one of the most important RES: between 1990 and 2015, the average annual growth rate of wind power (in terms of generating capacity) for world energy supply was about $24 \%$, second only to solar photovoltaic (45.5\%) (IEA, 2017, a). Wind energy now makes up $4 \%$ of global

\footnotetext{
${ }^{1}$ Around $85 \%$ of wind power capacity worldwide is installed in just ten countries: China, the USA, Germany, India, Spain, the UK, France, Brazil, Canada and Italy (Sawyer et al., 2018).
} 
RES (IEA, 2017a), guaranteeing an electricity production in 2015 of about 838 TWh (IEA, 2017, b). In comparison to the other RES, wind power provides simultaneously a high efficiency of electricity production (24-54\%), cheap electrical energy ${ }^{2}$ and the lowest greenhouse gas emissions (around $25 \mathrm{~g} / \mathrm{kW} \mathrm{h} \mathrm{CO}_{2-\mathrm{e}}$ ) (Evans et al., 2009). Moreover, if we consider the wind power cycle over time, it requires less land than the fossil, nuclear, biomass and hydro fuel cycles (Fthenakis \& Kim, 2009). Perhaps for all of these reasons, the image of WTs often used in advertising can be said to represent - especially for 'outsiders' (meaning the people who do not live close to the wind farm) - almost a sort of icon of RES.

However, as many authors have pointed out (see, for example, Saidur et al., 2011; Wang \& Wang, 2015), wind power also has some negative effects on the environment, such as its impact on wildlife (mainly on birds and bats) and land occupation. For the people living in the proximity of WTs, however, the most significant negative impacts are the noise (from the constant movement of the rotor blades) and the damage to the views and the aesthetics of the landscape (i.e., Pedersen et al., 2007). Nevertheless, since noise levels drop at a fairly short distance, (i.e., Barlas et al., 2017), few people are involved. The visual and aesthetic impact, on the other hand, affects a much wider area, and is sometimes the main reason for opposition to a newly proposed wind farm (Petrova, 2013).

Assessing the objective visual threshold of a wind farm is thus very important in order to support the planning and decision process for new power plants; it can be difficult, though, because it involves numerous factors such as the visual size and contrast, the landscape setting and the features of the object (Shang \& Bishop, 2000). The height of towers, their total number, their color and the rotor diameter, the moving blades and the general layout of the wind farm are all key elements in how the visual impact of the WTs is defined, not to mention features of the terrain such as topography, land cover and management, and the network of human settlements (such as Torres Sibille et al., 2009; Warren et al., 2005). Several studies have tried to assess the visibility of WTs using mainly a GIS-based approach (such as Hurtado et al., 2004; Möller, 2006; Molina-Ruiz et al., 2011) or one supported by analysis of photographs (such as Lothian, 2008; Jallouli \& Moureau, 2009; Vissering et al., 2011; Betakova et al., 2015) or a combination of the two (i.e., Tsoutsos et al., 2008). However, since the perceived visual impact of WTs usually "remains in the eye of the beholder" (Bishop, 2002), when assessing local acceptance of a wind farm, it is important to take into account the subjective component in any aesthetic quality evaluation of a landscape. Perception, cognition and emotion are crucial psychological elements in the human observer (Daniel, 2001), so it is important to 'objectivize' the visual impact assessment by focusing on "respondent characteristic" (Molnarova et al., 2012; Sklenicka \& Zouhar, 2018).

For these reasons, the distance factor, too, is an open question. In 2002, Bishop stressed how, even in clear air, the visual impact of WTs (50 m height; 3-blade rotor; blade $26 \mathrm{~m}$ long) "becomes minimal beyond 5-7 km". For Tsoutsos et al. (2009) the blades' motion extends the visual zone affected by WTs, so their presence can be observed as far as $8 \mathrm{~km}$. The guidelines of Scottish Natural Heritage (University of Newcastle, 2002), on the other hand, propose three specific distances for the recommended 'zone of visual influence': it suggests a landscape dominated by WTs in the first Km of distance (the 'immediate area'); the view is mainly occupied by WTs and by the attractive motion of their blades also in the 'intermediate area' (between 1 and $10 \mathrm{~km}$ ); on the other hand, the WTs visual impact become minimal only after $10 \mathrm{Km}$ (the 'distant area'). Instead, Knies and Gräfe (2011) suggest threshold values quite lower: similarly to the Scottish Natural

\footnotetext{
${ }^{2}$ After collecting a large number of literature sources, Evans et al. (2009) estimated that the mean price of wind electricity is $0.07 \mathrm{USD} / \mathrm{kWh}$. Actually, this is average cost of electricity generation has a wide range of variability, after accounting for all the steps usually included in a life cycle analysis procedure (construction, installation/commissioning, operation, maintenance, decommissioning, recycling and/or disposal). Even if the wind costs can be "minimized by careful selection of suitably sized generators, according to the quality of the site-specific wind resource", this price can only be considered competitive as long as there are favorable general economic conditions. A good example of this is Spain: recent political policies designed to make the energy market more balanced and sustainable have made the construction of new wind farms unprofitable, substantially stopping growth in the wind sector since 2012 (see Section 6).
} 
Heritage, they detect several zones of visual impact (proximity, foreground, middle distance, distant view and far distance) for WTs with different heights $(80 \mathrm{~m}, 100 \mathrm{~m}$ and $150 \mathrm{~m})$, but the proposed visual thresholds are very close to the WT for the 'distant view' zone $(1.5 \mathrm{~km}, 2 \mathrm{~km}$ and $2.8 \mathrm{~km}$, respectively), while the upper limit of the 'far view 'zone is between $30 \mathrm{~km}$ and $40 \mathrm{~km}$. Vissering et al. (2011) too, in view of the rapid developments in WT technology, suggests that in clear weather conditions, modern WTs with a power capacity of $2 \mathrm{MW}$ (or more) can easily be seen from a distance of more than $30 \mathrm{Km}$. While agreeing about the changes in the visibility of WTs due to their rapidly increasing height, Sullivan et al. (2014) still proposes lower limits for their visual impact (between 19 and $37 \mathrm{~km}$ ). Betakova et al. (2015), on the other hand, propose a different definition of 'the most and the least attractive landscape': in the former, the negative visual impact of WTs disappears after $10 \mathrm{~km}$ while, in the latter, it disappears after $5 \mathrm{~km}$. Without being exhaustive (Table 1), it should have become fairly clear by now that it is very difficult when one is dealing with objective data (i.e. the height of the tower, the size of the WT, etc.) regarding a fast-developing technology which then must somehow be interfaced with differing subjective evaluations of the insiders (who live within the region) and/or the outsiders (the casual viewers).

\begin{tabular}{l|c|l} 
Authors (year) & Visual Impact (VI) & Notes \\
\hline $\begin{array}{l}\text { Knies and Gräfe (2011) } \\
\text { Bishop (2002) }\end{array}$ & $2.8 / 40 \mathrm{~km}$ & Initial border of 'distant view' / upper limit (for a WT 150 m height) \\
$\begin{array}{l}\text { Tsoutsos et al. (2009) } \\
\text { Scottish Natural Heritage (2002) }\end{array}$ & $5-7 \mathrm{~km}$ & Range of VI limits (for a WT of maximum 75 m height) \\
$\begin{array}{l}\text { Betakova et al. (2015) } \\
\text { Vissering et al. (2011) }\end{array}$ & $10 \mathrm{Km}$ & VI influenced by blade motions \\
\hline Sullivan et al. (2014) & $5 / 10 \mathrm{Km}$ & Initial border of 'distant area' \\
\hline
\end{tabular}

Table 1. Some examples of different proposals for the visual impact (VI) of WT.

The main purpose of this paper, however, is to draw attention to the astonishing growth in the number of WTs in those EU countries which are presently playing a key role in wind power. More specifically, we intend to map the EU regions characterized by a very high concentration of WTs, so as to obtain a clear idea of the actual size of these new "windscapes". Our data source is OpenStreetMap (OSM), one of the most popular platforms which uses volunteered geographic information (VGI) supplied by people collecting geospatial data using a GPS or finding positions through an Internet web mapping service such as Google satellite (Goodchild, 2007). The OSM is an international project which started in the UK in the early 2000s and developed in order to create and provide free global topographic maps (see Bennet, 2010; Ramm et al., 2011). While at the beginning, the VGI was mainly focused on road network data, attention has now shifted to real-world features, such as buildings or land use (i.e., Neis \& Zielstra, 2014). At present, there are many different tags (cfr. Section 3) used to provide VGI to OSM in order to map almost everything. With regard to RES, VGI maps photovoltaic farms (Mauro \& Lughi, 2017), biomass and biofuel plants, hydroelectric dams, and so on. It is therefore possible to automatically extract the exact location of WTs using geographical information system (GIS) software (see Borrough, 1990) such as, QuantumGIS. Various data can be obtained from this software, such as the geographical distribution of WTs within a given country, or the areas with a high concentration of WTs.

This paper is organized as follows: Section 2 contains a brief description of wind supply in EU; Section 3 provides more details about the OSM project and the potentially available data; Section 4 describes the methodology used; Section 5 presents the main results; Section 6 discusses the results; and Section 7 contains the concluding remarks.

\section{Wind energy development in Europe}


The wind energy sector has seen exponential growth since the turn of the century. In recent years, there have also been significant changes in its geographical distribution (Table 2), and by the end of 2010, China had become the new world leader (188,392 MW in 2017).

\begin{tabular}{|l|c|c|c|c|}
\hline & MW & $\begin{array}{c}\text { Share of World total } \\
(\%)\end{array}$ & MW & $\begin{array}{c}\text { Share of World } \\
\text { total (\%) }\end{array}$ \\
\hline EU & 18,040 & 73.3 & 177,506 & 32.9 \\
\hline USA & 2,564 & 14.2 & 89,077 & 16.5 \\
\hline East Asia & 492 & 2.7 & 228,684 & 42,4 \\
\hline
\end{tabular}

Table 2. Wind energy sector development (2000-2010). Sources: Dent, 2013; Sawyer et al., 2018.

At the beginning of 2000 , the EU was the world leader, with $73.3 \%$ of global installed capacity $(18,040 \mathrm{MW})$, while in the same year, the USA accounted for 14.2\% and East Asia for 2.7\% (Dent, 2013). By the end of 2010, China had become the new world leader (44,733 MW in 2010 rising to 188,392 MW in 2017). East Asia now accounts for $42.4 \%$ of global installed capacity $(539,123 \mathrm{MW})$, followed by the EU (177,506 MW; 32.9\%) and the USA (89,077MW; 16.5\%) (Sawyer et al., 2018).

As is well known, the EU countries set their different targets in the renewable energies Directive $(2009 / 28 / \mathrm{Ce})$ aiming to achieve $20 \%$ of total energy consumption from RES by $2020^{3}$. The EU is now very close to reaching the 2020 target, mainly thanks to faster growth in the photovoltaic and wind sectors (Arantegui \& Jäger-Waldau, 2018). In 2017, the production of wind energy (336 TWh) alone covered $11.6 \%$ of EU electricity demand (2,906 TWh), becoming the second biggest form of power generation capacity after gas (Fraile \& Mbistrova, 2018). 2018). Germany is the third in the world for its wind-power capacity (WPC) and the biggest producer in the EU, followed by Spain, the UK, France and Italy (Table 3). Overall, the WPC of several EU countries is comparable to (or sometimes higher than) other traditional or rising global economic powerhouses such as Canada (12,239 MW), India (22,848 MW) or Brazil (12,773 MW) (Sawyer et al., 2018). Denmark is the EU country with the largest share of its electricity demand covered by wind energy (44\%, of which $16 \%$ of offshore), followed by Portugal and Ireland $(24.2 \%$ and $24 \%$ respectively, almost exclusively onshore), Germany (20.8\%, about $3 \%$ offshore) and Spain (18.6\%, almost exclusively onshore) (Fraile \& Mbistrova, 2018). Germany and Denmark are the EU countries with the highest WPC density (estimated as $\mathrm{MW} / \mathrm{Km}^{2}$ ), followed by Netherlands, Belgium and the UK (Table 3 ).

WPC

Wind energy penetration rate

\begin{tabular}{|c|c|c|c|}
\hline Country & $\%$ & Country & $\mathrm{KW} / \mathrm{Km}^{2}$ \\
\hline Denmark & 44.4 & Germany & 142 \\
\hline Portugal & 24.2 & Denmark & 130 \\
\hline Ireland & 24.0 & Netherlands & 101 \\
\hline Germany & 20.8 & Belgium & 94 \\
\hline Spain & 18.6 & United Kingdom & 82 \\
\hline
\end{tabular}

Table 3. The top five EU28 Countries for their wind power capacity (WPC) (source: Fraile \& Mbistrova, 2018); for wind energy penetration rate (percentage of the average electricity demand covered by wind; source: Fraile \& Mbistrova, 2018) and for WPC spatial penetration (source: IEA, 2018).

For a more detailed comparison, the complete table can be found in the appendix 1.

Given the above, since the paper intends to map EU regions with a high concentration of WTs, we consider the geographical distribution of windmills in the ten countries - Germany, Spain, United Kingdom, France,

\footnotetext{
3 The recent agreement "2030 Climate and Energy framework" adopted by EU leaders in October 2014, raises targets to at least a $27 \%$ share for renewable energy by 2030 .
} 
Italy, Denmark, Portugal, Ireland, Netherlands and Belgium - which according to various parameters (either WPC or wind energy penetration rate or WPC density) are the key players in wind energy among the EU28.

\section{Data source: the crowdsourcing data of OpenStreetMap (OSM)}

In the composite world of map-making, greatly influenced by modern information technology but also by the creative efforts of cartographers, OSM represents a significant breakthrough. Created in 2004 by Steve Coast, a British programmer, who had the idea of building and distributing a free editable map of the world, OSM is now a very valuable resource for geographical data. In just a few years, this project has grown exponentially: at the time of writing, it has more than 4.2 million registered members, although only around $1 \%$ of these are 'active users' (OSM statistics, http://www.openstreetmap.org/stats/data stats.html, accessed 20 November 2018). In real terms, this means that more than 40,000 people around the world - the VGI -are directly involved during their spare time in mapping (or updating), in collecting GPS tracks, or in using other cartographic sources (such as Yahoo's vertical aerial photography database or Microsoft's Bing Map or again, official data released from various governments around the world; Curran et al., 2012).

The digital map is freely available from the project's main website (www.openstreetmap.org) and can be used in different ways to obtain information about numerous points of interest through geocoded locations (Maier, 2014). Obviously, quality assessment is still one of the most important critical issues of OSM, representing a key issue for the OSM Community. Several studies have pointed out the high quality of the crowdsourced map (i.e., Zieltra \& Hocmair, 2011; Almendros-Jemenéz \& Becerra-Terón, 2018). However, the huge dataset generated by VGI from people with different levels of mapping experience and technical skills can create anomalies such as overlapping features, length completeness, missing attributes and duplicate points (Kaur et al., 2017).

VGI modify the OSM PostgreSQL database, by mapping point information (represented by node objects) or lines and polygons (represented by way objects). The key component of OSM is its main database, which contains tables for each element type (nodes, ways and relations). In OSM, the attribute information of each object is referred to as a 'tag'. It consists of a 'key' and a 'value' used to store metadata: the first describes a broad class of features (e.g., an amenity, a building, tourism, etc.), the second details the specific feature that was generally classified by the key (e.g., for amenity = a cinema). Finally, relations are sometimes used to explain a relationship between node and way (Ramm et al., 2011).

For the mapping of electrical power lines or associated infrastructure, the key tag is 'power', while the 'generator' is the value describing a device converting one kind of power to another (i.e., WT, gas turbine, single solar panel, hydroelectric turbine, etc.). The compulsory attribute linked to the value generator may vary. The 'source' refers to the power source of the energy such as wind, solar, hydro, coal, and so on. The 'method' refers to the technique used for power generation, therefore: WT, solar photovoltaic, hydro waterstorage, etc. Finally, the 'type' refers to the category of generator, such as horizontal turbine, solar photovoltaic panels, etc.

However, it can sometimes be difficult for the VGI to identify the WTs clearly on the map (fig.1). Actually, this kind of land use is a very detailed geographical information - a point spatial object - frequently displayed (and visible) only on a large-scale map (i.e. 1:2.000). For this reason, it may not be easy to map. 


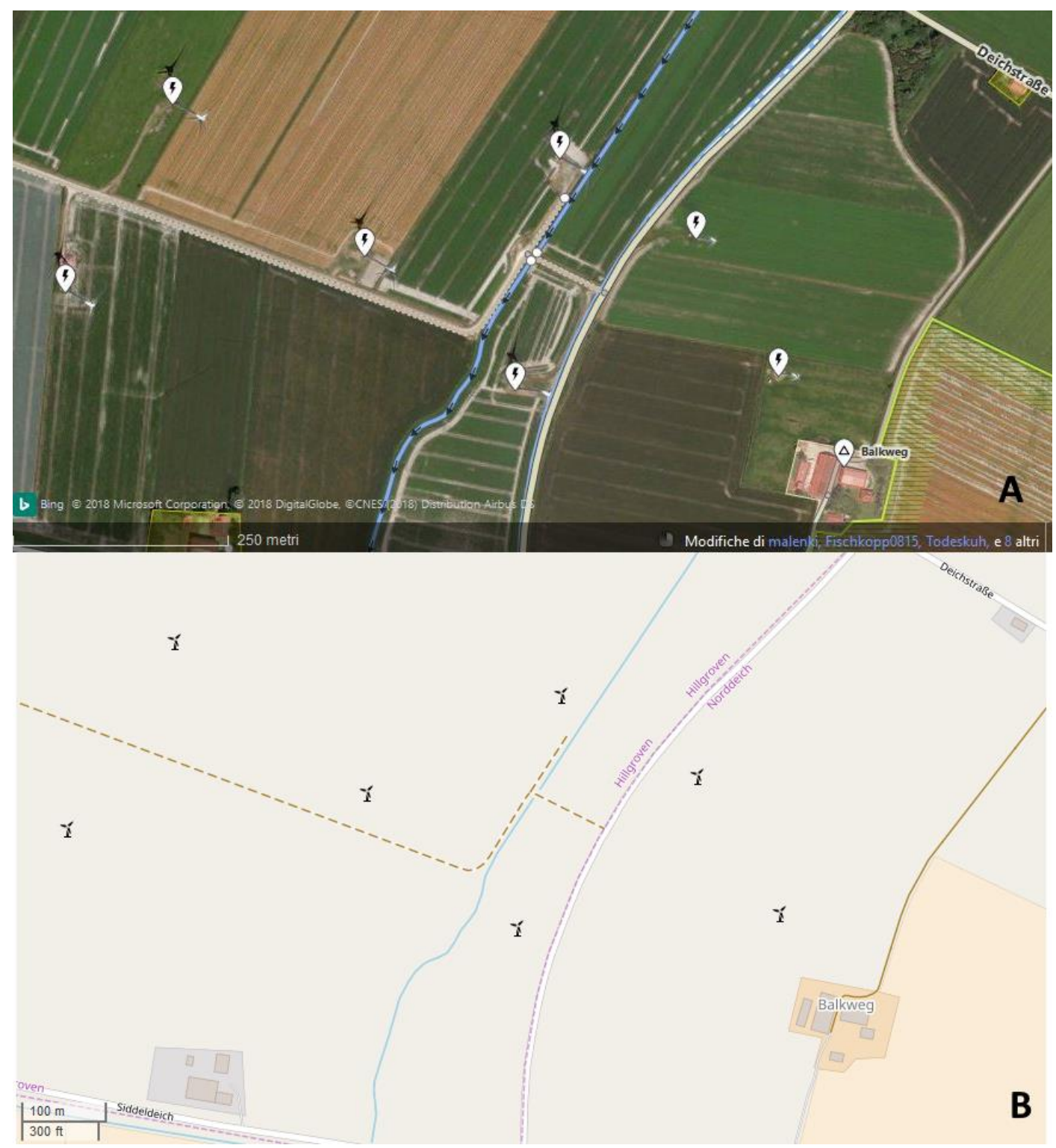

Figure 1. The WTs mapping process in an OSM map: an example near Hillgroven, a small town close to Wesselburen in Schleswig-Holstein (Germany). 1A: identification of WTs on the Microsoft Bing Satellite base map; 1B: the resulting detailed map of OSM.

\section{Methodology}

A schematic overview of the data processing is shown in figure 2 .

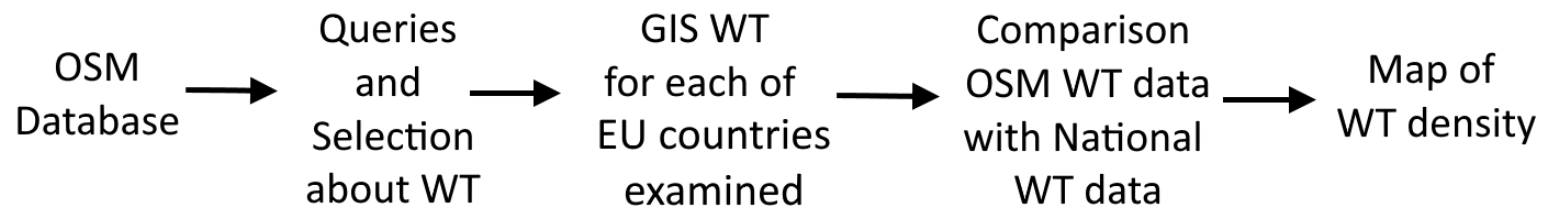

Figure 2. Schematic overview of the data processing work flow for deriving the map of WT density in the study area. 
OSM, then, is the main data source used to map the location of WTs in the ten countries examined. Wind attribute is taken as the 'generator source' and WTs as the 'generator method'. Using an open-source GIS software - Quantum GIS (QGIS) - the user can easily set up queries on the OSM database and save the results in a new cartographic layer in proprietary format (.osm file $)^{4}$. It is then possible to convert these geographical data into a more generic cartographic format (i.e. a shapefile). Given the scale of the study area, our detailed queries can usually only cover a small portion of the whole surface of one examined country. Since we usually work at a chorographic scale (about 1:1,000,000), this often means producing several maps to cover an entire country ${ }^{5}$. Of course, these files have then to be merged into a single cartography in order to locate all the WTs in each country, being careful to delete the duplicate geometries created in overlapping areas. Finally, the only points considered are the ones that fall inside the borders of the country under examination (this study does not include any offshore wind parks). In this way, a base map is created, called 'GIS WTs' (the 'GIS of onshore wind turbines') - where every WT in each of the countries included in the study area is located. In order to validate our cartographic results, we need to compare the data of 'GIS WTs' with official data regarding the WTs of each EU country (see Section 5.1). Actually, it is not easy to obtain these data, because all the available statistics about wind energy usually regard either its capacity [expressed as watts (W) or multiple] or its productivity [expressed as watts per hour (Wh) or multiple]. However, the various countries have national wind energy agencies ${ }^{6}$ which usually provide the number of wind parks and more specifically, the number of WTs present within their borders.

Once the 'GIS WT' for each EU country involved in the study has been validated, a point density map was created; this makes it easier to evaluate the spatial distribution of windmills within the entire study area. We calculated the density of point features around each output raster cell, so the final heat map shows where the highest concentration of features is. Taking each point as a WT, the search radius is assumed to correspond to its visual impact threshold: in this way, we try to make a rough estimation of the overall visual impact of the WTs in the study area. As is well-known, it is difficult to define the distance as regards visual impact for several reasons (see Section1), and it becomes even harder when we bear in mind the landscape diversity within the ten countries examined. Based on the above information about the visual impact of WTs (expressed in $\mathrm{Km}$; see Section 1), we suggest a neighborhood with a search radius roughly equal to $10 \mathrm{Km}^{7}$. We apply a 'point density' function in order to obtain WT density, dividing the number of WTs within this circle by its area (about $314 \mathrm{Km}^{2}$ ). As pointed out by Carlos et al. (2010), this relatively simple approach is 'appropriate for studies which are interested in the number of events per unit area at a specified location' when we do not expect attenuation with distance (as we would in the case of environmental pollutants, for instance). We thus created a raster map of WT density for each examined country; in this map, the value of 'point density' is associated with the single cell. In fact, as pointed out by Mitchell (1999), in order to create a point density map "the GIS move in the next cell and do the same". It is very important to decide on the

\footnotetext{
${ }^{4}$ Actually we used a Quantum GIS plugin, Quick OSM: it works in the current version of this software (QGIS 3.2) and it easy support for OpenStreetMap raw vector data.

${ }^{5}$ In the case of Spain, for instance, more than twenty-five shapefiles were created.

${ }^{6}$ They are the following: Association de Promotion des Energies Renouvelables (APERe) for Belgium; Danish Energy Agency (DEA) for Denmark; France Énergie Éolienne (FEE) for France; Deutsche WindGuard for Germany; International Energy Agency IEA) for Ireland and Netherlans; Agenzia Nazionale Energia del Vento (ANEV) for Italy; Associação Portuguesa de Energias Renováveis (APREN) for Portugal; Asociación Empresarial Eólica (AEE) for Spain; UK Wind Energy Database (UKWED) for United Kingdom.

${ }^{7}$ As already pointed out (see Section 1) there is no clear indication in the literature about VI (Table1). Furthermore, recent technological developments in the wind sector mean that today's wind turbines tend to be higher than those of just a few years ago (as pointed out by Sullivan et al., 2014; Section 1). This is particularly true in those countries which have opted for repowering strategies, such as Denmark and Germany (see Section 6). For these reasons we chose a greater distance than the one suggested by Bishop in $2002(5-7 \mathrm{~km})$, but it is still shorter than that suggested by other more recent authors. In any case, also if it remain a subjective matter, we regard it as a prudent choice (also confirmed by some survey in the field), made in order to avoid the risk of overestimating the visual impact of wind turbines.
} 
size of this cell, then, because it determines how coarse or fine the pattern will appear: we chose a cell size of $200 \mathrm{~m}$, so the resulting continental map is very fine ${ }^{8}$.

Finally, all ten WT density maps generated for each country were merged to obtain a single map of WT density within the study area. This raster map was then classified (Fig.3) according to five classes of WT density: very low, low, medium, high and very high (algorithm of classification: natural breaks, five classes; excluded value: 0 ) (see Table 4). To make things clearer, an area with a density greater than $0.628 \mathrm{WTs} / \mathrm{Km}^{2}$ (very high) means that more than 200 WTs are present in a circle with a radius of $10 \mathrm{Km}$.

For example, Figure 3 shows the results for the Netherlands. Figure 3A is a map of all the WTs extracted from OSM, while Figure $3 B$ is the map showing WT density $\left(\mathrm{WTs} / \mathrm{Km}^{2}\right.$ ), automatically classified (algorithm of classification: "natural breaks" ${ }^{9}$ ) into our five classes.

\begin{tabular}{c|c} 
Density & WTs $/ \mathrm{Km}^{2}$ \\
\hline Very low & $<0.058$ \\
Low & $0.058-0.156$ \\
Medium & $0.157-0.318$ \\
High & $0.319-0.628$ \\
Very high & $>0.639$
\end{tabular}

Table 4. The threshold pixel values in order to classify the heatmap of WTs in the analyzed Countries.
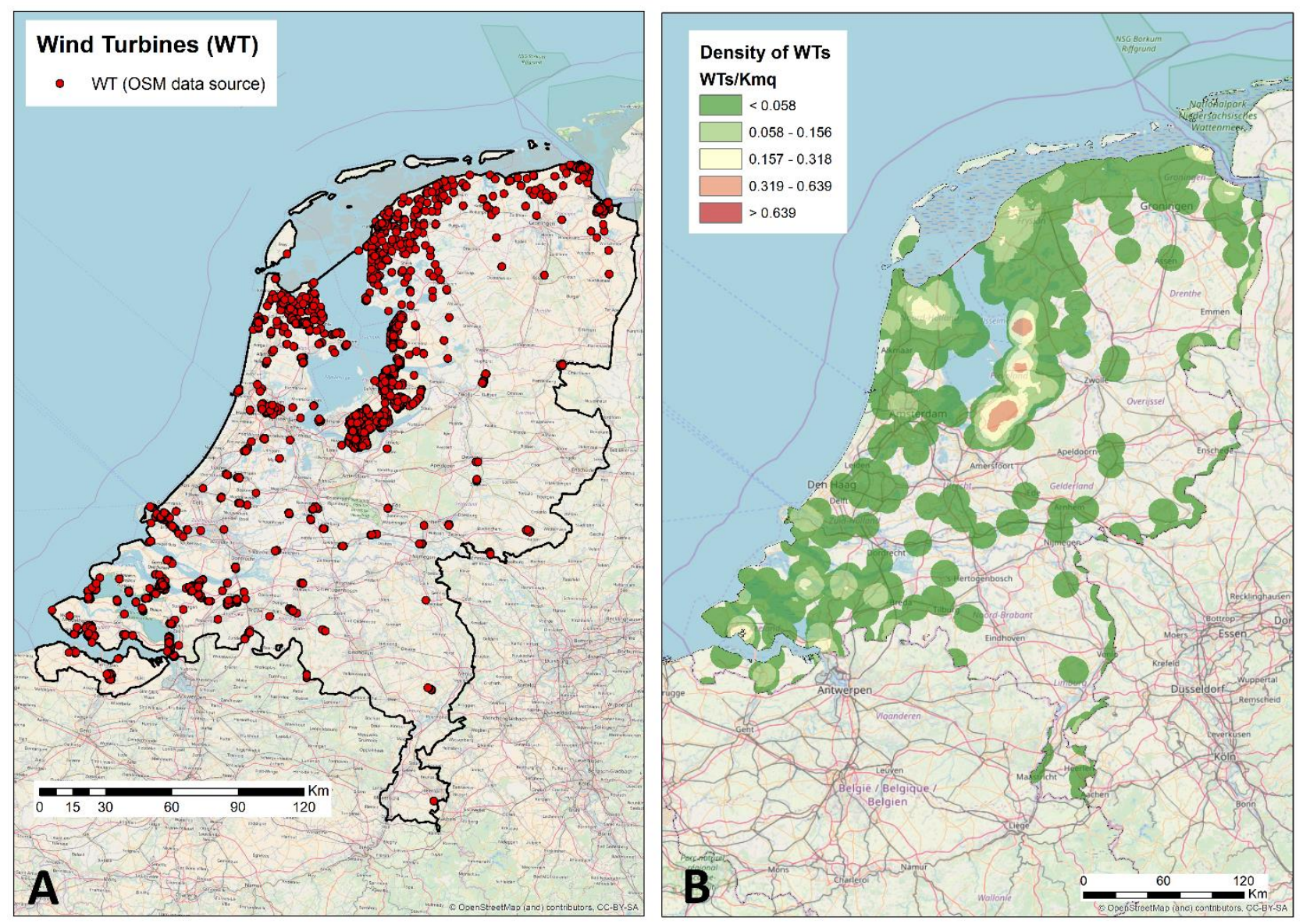

Figure 3. The Netherlands case study. 3A: the map of WTs derived from OSM, and 3B: the WT density map. Base Map: OpenStreetMap.

\footnotetext{
${ }^{8}$ Given the relationship between the ground of 'graphicism error' (conventionally equal to $0.25 \mathrm{~mm}$ ) and cell size (200 $\mathrm{m}$ ), the scale factor of the resulting map of WT density is about 1:8,000 (Favretto, 2014).

${ }^{9}$ Using this algorithm, raw data are classified into groups with similar values. The output map better highlights differences between highest and lower block groups (Mitchell, 1999). In this specific case, we excluded the zero values.
} 


\section{Results}

\subsection{A comparison between the national data and OSM estimations}

Obviously, In order to validate our cartographic results, we need to compare the number of WTs officially reported by each country with the OSM data. As explained above, the data are provided on a national basis because the information regarding WTs is not usually available on a more detailed scale (i.e. at the regional or provincial level).

As Table 5 shows, OSM data tend to be lower than the official figures, especially for the UK (-29.7\%), Portugal $(-15.8 \%)$, France $(-15.7 \%)$ and Belgium $(-15.4 \%)^{10}$. This difference highlights a widespread difficulty in the mapping process experienced by OSM users: as mentioned in section 3, it is not easy to clearly pinpoint on the map such precise data as WTs (see fig. 1). Of course, there might be other reasons for this discrepancy: the size of the wind farm might be more difficult to detect if its power capacity is below $500 \mathrm{KW}$; the level of upgrade of the OSM base maps can also make a difference, because if they are out of date, the VGI cannot map the presence of the WT; network availability differs in the internal areas; etc.

$\begin{array}{lcccl}\text { Country } & \begin{array}{c}\text { OSM } \\ \text { Estimation }\end{array} & \text { National Data } & \text { Difference (\%) } & \text { Source } \\ \text { Belgium } & 751 & 888 & -15.4 & \text { APERe, 2018 } \\ \text { Denmark } & 5,442 & 5,701 & -4.5 & \text { DEA, 2018 } \\ \text { France } & 5,561 & 6,600 & -15.7 & \text { FEE, 2017 } \\ \text { Germany } & 25,916 & 28,675 & -9.6 & \text { Deutsche WindGuard, 2018 } \\ \text { Ireland } & 1,548 & 1,503 & 3.0 & \text { IEA Wind, 2016 } \\ \text { Italy } & 6,170 & 6,729 & -8.3 & \text { ANEV, 2018 } \\ \text { Netherlands } & 2,027 & 2,174 & -6.8 & \text { IEA Wind,2016 } \\ \text { Portugal } & 2,324 & 2,759 & -15.8 & \text { APREN, 2018 } \\ \text { Spain } & 19,025 & 20,292 & -6.2 & \text { AEE, 2017 } \\ \text { UK } & 4,974 & 7,074 & -29.7 & \text { UKWED, 2018 } \\ \text { Total } & 75,672 & 85,451 & -11.8 & \end{array}$

Table 5. Comparison between OSM data and national data regarding WT numbers in the countries examined.

\subsection{The spatial distribution of WTs in the countries of the study area}

Despite this shortfall, the OSM has mapped more than 75,000 WTs in the ten EU countries examined. Their spatial distribution within the study area (Fig. 4) is heterogeneous: in some cases, their presence is almost ubiquitous (as in Germany and Denmark) or quite widespread (as in Belgium and the Netherlands). In a few countries, on the other hand, there is a high density of WTs concentrated in just a few areas (as in Spain, Portugal and Italy). In the remaining countries, there is a low density of WTs widely distributed all over the country (as in UK and Ireland) or concentrated in only one single area (as in France). A comparison with the European map of wind power drawn up by Troen and Petersen in 1989 (Fig.5) points to the importance of the individual wind energy policies adopted by each EU28 member state. As shown in Table 6, windscapes "visually" occupy almost $600,000 \mathrm{Km}^{2}$, which makes up more than a quarter of the study area (about $27 \%$ ) however, the presence of WTs can be described as invasive (of a high and very high density) in an area covering more than $10,500 \mathrm{~km}^{2}$ (less than $0.5 \%$ of the territory considered). Furthermore, we estimate that

\footnotetext{
${ }^{10}$ For Ireland, on the other hand, the OSM number is an overestimate $(+3 \%)$, probably because the official figures provided regarding WTs are out of date (IEA Wind, 2016).
} 
more than $1,350 \mathrm{Km}^{2}$ of the land with a very high density of WTs is distributed either along the coasts or in the internal areas of just four countries (Germany, Italy, Spain and the United Kingdom).

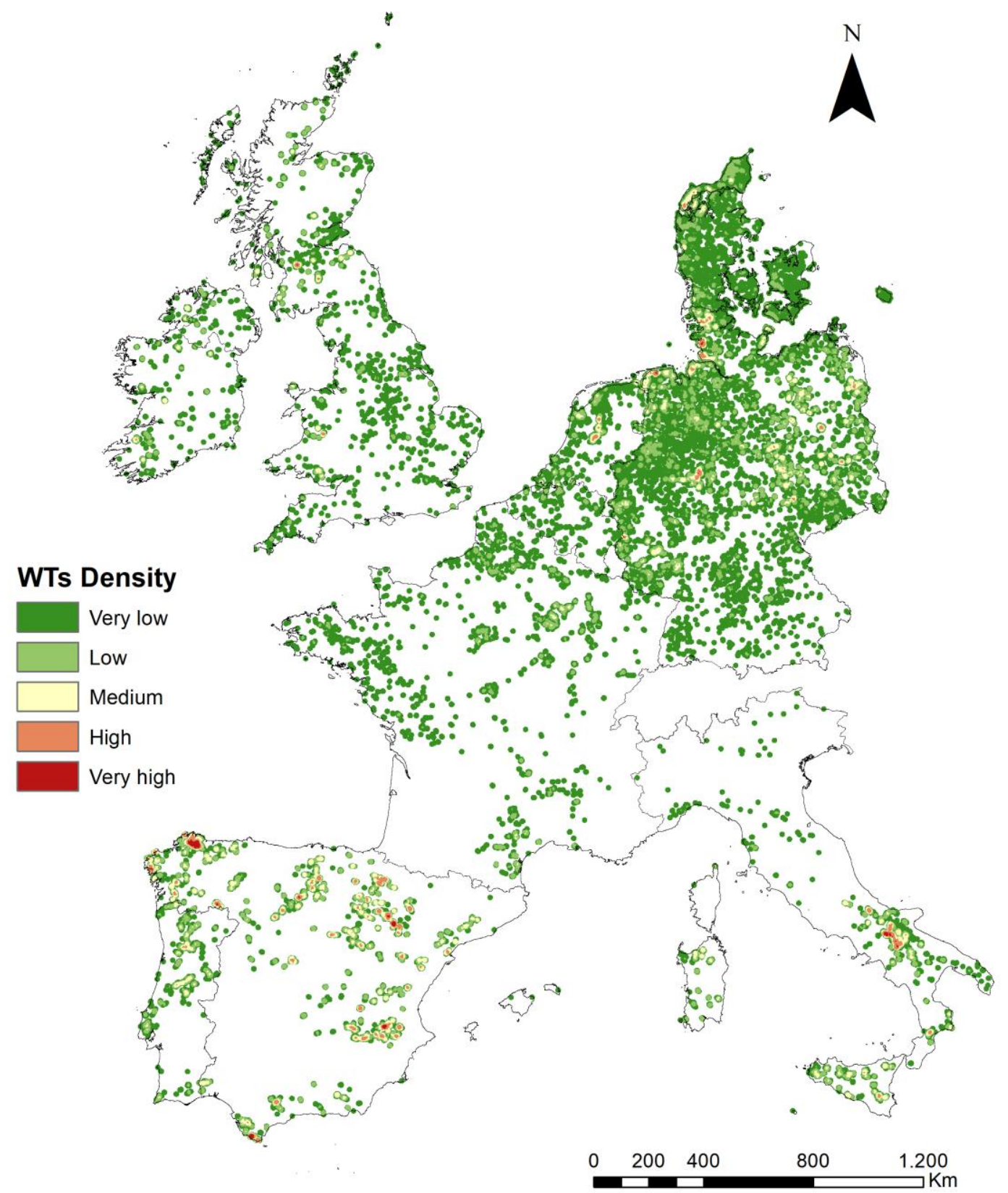

Figure 4. The spatial distribution of WTs in the EU countries examined (algorithm of classification: natural breaks, five classes; excluded value: 0). 


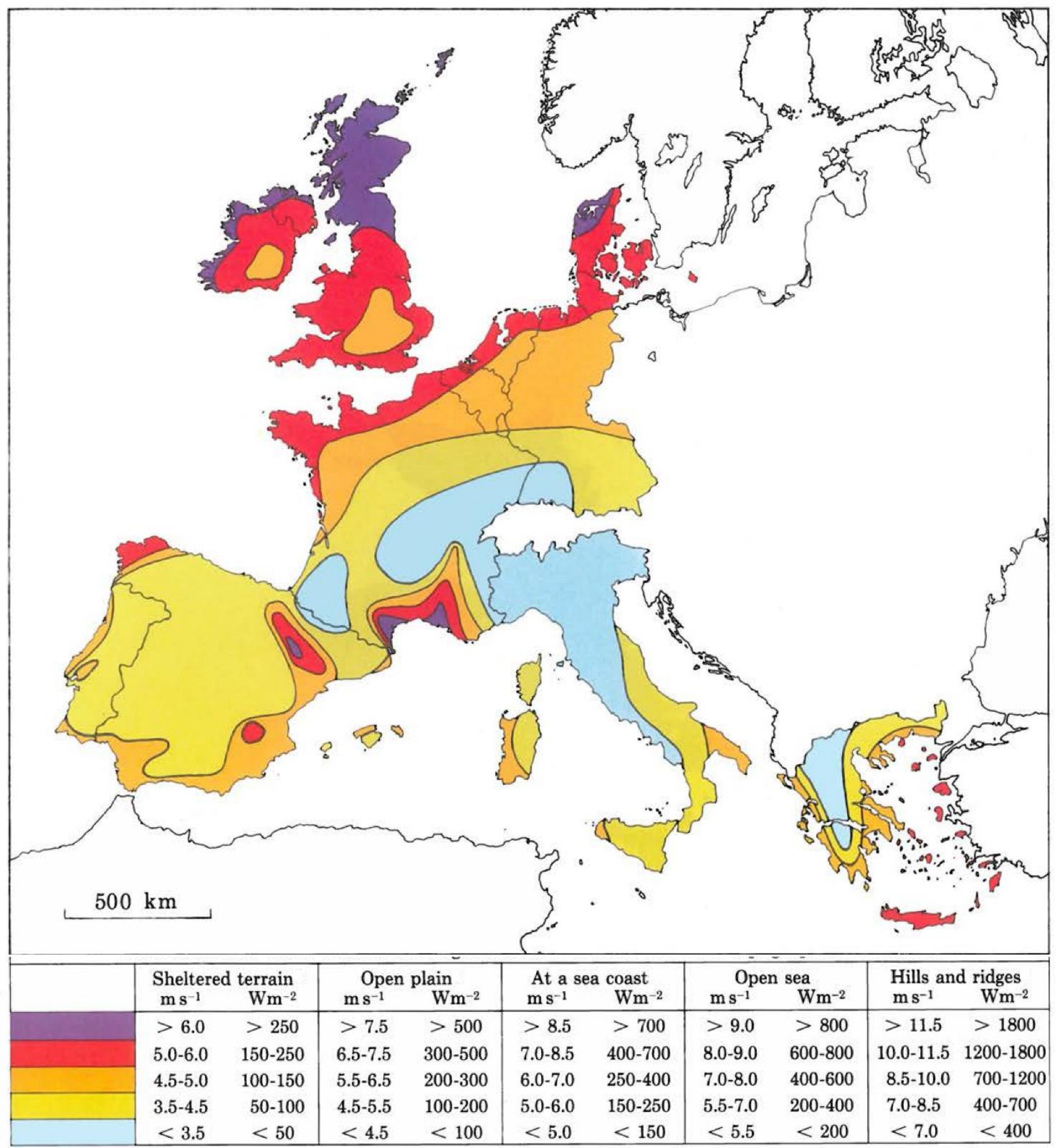

Figure 5. Wind resources at 50 meters above ground level for five different topographic conditions (Source: Troen \& Petersen, 1989, mod.).

After almost thirty years of policies in support of wind energy ${ }^{11}$, German is the EU country with the widest geographical distribution of WTs. Generally owned by small operators with limited assets (Ziegler et al., 2018), wind farms are widely distributed almost all over the country, "visually occupying" nearly $60 \%$ of the landscape (Table 6). Since the windfarms are often small, however, in 57\% of these cases the density of WTs is either low or very low. The remaining 3\% - comprising the areas of medium, high and very high concentrations of WTs - is only partially distributed where the windiest weather is to be found, i.e. along the

\footnotetext{
11 Already at the end of the 1980s, the Germany government adopted the "100/250 MW Program" for wind power development. It subsequently approved the "Electricity Feed-in Law" in 1991 and in 1997, the Federal Building Code declared WTs to be "privileged building projects" (Saidur et al., 2010).
} 
Baltic coast (Fig. 6). Although these are the areas (mainly on the west coast) with the highest density of WTs ${ }^{12}$, they are also very numerous in the centre of Germany (North Rhine-Westphalia and Hesse) and in the east (Brandenburg and Saxony-Anhalt) (Fig. 6A).

As is well-known, Denmark has a long tradition of developing wind power. However, while its offshore wind farms continue to grow, construction of onshore WTs (which is mainly under the control of local cooperative ownership requiring social involvement) has almost ceased (Möller, 2006). Since 2012, new energy policies are in place which promote the replacement of older WT with more efficient ones, with the aim of reducing their numbers by around a quarter by 2020, at the same time as increasing the share of wind power in Danish electricity consumption. The map of WT distribution (fig.6A) indicates the great visual presence of windmills throughout this country (almost 90\%), though usually at low concentrations (78\%). In this regard, the highest density of WTs is to be found along the western coastline and in particular near the Limfjord region close to Nordjylland (the northern district of Denmark) (Fig.7A). All these zones, where the best Danish wind conditions exist (Fig. 5), are areas with a low-density population (Laursen \& Anderson, 2011), characterized mainly by small town and villages.
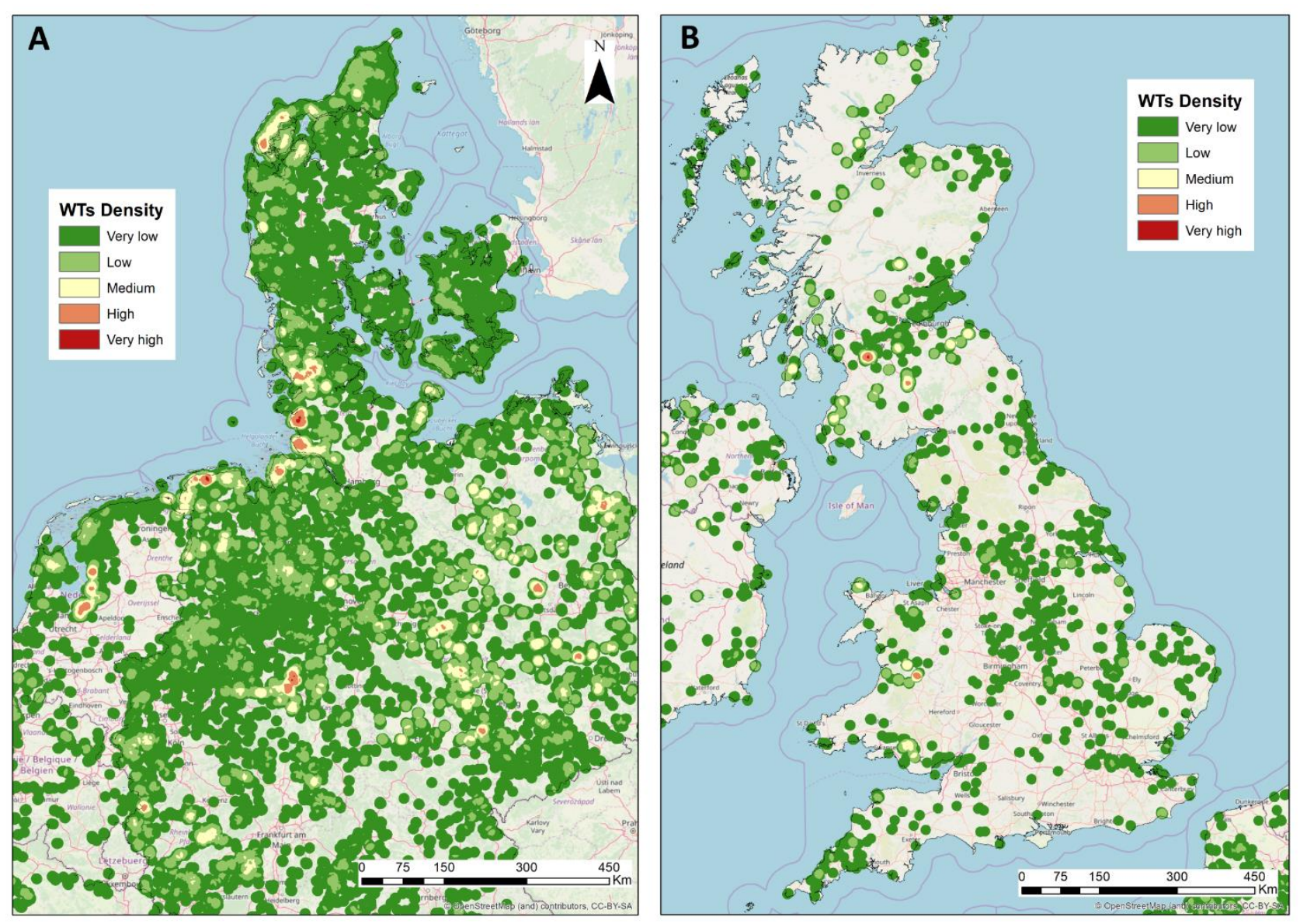

Figure 6. Spatial distribution of WTs in central Europe (A) and the United Kingdom (B). Base Map: OSM.

Although the UK and Ireland have the best wind conditions for wind energy production in the EU (Fig.5), WT density is usually lower than in Germany or in Denmark. After an initially slow start (Mitchell \& Connors, 2004), WPC in the UK saw some impressive growth from $2.9 \mathrm{GW}$ in 2008 to $18.9 \mathrm{GW}$ in 2017, becoming in the process the world leader for offshore wind supply (7,155 MW in 2018). Underestimated by data source (see Section 5.1), the visual presence of WTs - frequently small wind farms - extends over only about 20-

\footnotetext{
${ }^{12}$ The WTs density is very high in three little zones, amounting to about $50 \mathrm{Km}^{2}$ namely the $0.01 \%$ of this country. The first is near the village of Heide in the northern State, the Schleswig-Holstein; the second near Essen in the northwestern Lower Saxony; the third is near Paderborn in the North Rhine-Westphalia.
} 
$25 \%$ of UK landscape. Wind turbines are usually widespread along the coastlines, mainly in Wales and in southern-central Scotland, where we also register a peak density (in an area of approximately $10 \mathrm{Km}^{2}$ ) close to Glasgow (fig. 6B) ${ }^{13}$. However, their visual presence is also quite pervasive along the Humber estuary and in several inland areas such as the central English regions of the East and West Midlands. In Ireland, the low density of population combined with windy and hilly landscapes offers optimal conditions, so wind farms are quite developed in its rural areas (often hilly or mountain moorland and along the coast). Moreover, wind power plays a central role in Irish energy policy with an eye to achieving its renewable energy target (Foley et al., 2013), ensuring 24\% of Irish power in 2017 (Fraile \& Mbistrova, 2018). As shown in Table 6, however, the visual presence of WT is fairly limited: their concentration is usually low and more widespread, occurring more frequently in the mid-west and south-west regions.

\begin{tabular}{|c|c|c|c|c|c|c|c|c|}
\hline Country & Null & $\begin{array}{l}\text { Very } \\
\text { low }\end{array}$ & Low & Medium & High & $\begin{array}{l}\text { Very } \\
\text { High }\end{array}$ & $\begin{array}{c}\text { Total } \\
\text { Windscapes } \\
\text { area }\end{array}$ & Country area \\
\hline & $\%$ & $\%$ & $\%$ & $\%$ & $\%$ & $\%$ & $K m^{2}$ & $K m^{2}$ \\
\hline Belgium & 58.75 & 39.89 & 1.29 & 0.07 & 0.003 & - & 12,594 & 30,528 \\
\hline Denmark & 11.45 & 78.21 & 8.35 & 1.83 & 0.16 & - & 38,160 & 43,094 \\
\hline France & 84.52 & 14.35 & 1.05 & 0.07 & - & - & 84,151 & 543,965 \\
\hline Germany & 40.62 & 49.42 & 7.39 & 2.22 & 0.34 & 0.01 & 212,127 & 357,237 \\
\hline Ireland & 79.95 & 17.32 & 1.92 & 0.77 & 0.04 & - & 14,092 & 70,285 \\
\hline Italy & 84.30 & 10.84 & 2.73 & 1.57 & 0.49 & 0.08 & 47,341 & 301,341 \\
\hline Netherlands & 52.25 & 40.39 & 4.81 & 2.00 & 0.55 & - & 19,829 & 41,526 \\
\hline Portugal & 74.87 & 17.88 & 5.03 & 2.11 & 0.11 & - & 23,077 & 91,831 \\
\hline Spain & 83.62 & 7.90 & 4.00 & 3.09 & 1.17 & 0.21 & 82,825 & 505,957 \\
\hline United Kingdom & 73.82 & 24.21 & 1.45 & 0.45 & 0.07 & 0.004 & 63,918 & 244,110 \\
\hline Total area $\left(\mathrm{Km}^{2}\right)$ & $1,631,696$ & 477,587 & 76,074 & 33,894 & 9,209 & 1,349 & 598,114 & $2,229,874$ \\
\hline
\end{tabular}

Table 6. Percentage and surface of area visually occupied by WTs, according to varying density in each of the countries examined (source of country area: De Agostini, 2000).

As regards the central west EU (including the Netherlands, Belgium and Central-Northern France), the presence of WT is quite widespread although there is a lower concentration than in Germany. In the Netherlands, despite the existence of national targets regarding RES and wind power, strong local opposition and an unfavorable support system have limited the installation of new windfarms (EEA, 2014). In spite of this, however, there is a low concentration of WTs which visually intrudes on almost $45 \%$ of Dutch landscape (Table 6). This is mostly due to the windfarms situated along its windy coasts: in fact, in recent years the Dutch government has mostly lent its support to the construction of offshore and nearshore wind parks. In the latter case, the turbines are often aligned along the dikes (which frequently meets with greater social acceptance; Wolsink, 2010), but also in the rural or industrial areas along the north coast, where wind speeds are highest. Several of these recently constructed windparks are in Flevoland Province (east of the metropolitan area of Amsterdam), which is where we recorded the peak level of WT concentration (Figs. 3B

\footnotetext{
${ }^{13}$ This is the Whitelee Wind Farm: with over 200 WT (for a total capacity of $539 \mathrm{MW}$ ), it is the biggest wind farm in all ten examined countries (https://www.scottishpower.co.uk/whitelee/).
} 
and 6A). Belgium, too, is expanding its WPC (mostly with offshore projects); windmills are widely distributed throughout the country, but the density is usually very low. They are mainly installed in northern and eastern Flanders, an industrialized, densely urbanized region (Pepermans \& Loots, 2013). They are frequently located in industrial areas (close to the highway network) or inside the port of Antwerp. In France, although the windy conditions and lie of the land are very favorable to the development of wind energy, for several reasons it started to grow later and more slowly than in other countries (such as Germany, for instance; Jobert et al., 2007). The obstacles were mostly of an administrative and legal nature, added to strong local opposition defending the landscape patrimoine. The number of new solar and wind facilities has grown impressively in recent years, however, bringing a rapid increase in the electricity mix of wind, solar and biomasses (Andriosopoulos \& Silvestre, 2017). The resulting distribution of WTs in France is therefore much like a fragmented patchwork. Wind farms are mainly located in the northern regions (Hauts-de-France and Grand Est) and along the west coast (Bretagne and Pays de la Loire), probably due to the higher wind speeds and flat terrain (Enevoldsen \& Sovacool, 2016). In the regions bordering the metropolitan area of Paris (an average distance of between 60 and $120 \mathrm{~km}$ from Paris), there are several areas characterized by a medium concentration of WTs. In the south, their density is limited to several small wind farms in the near coastal area of Occitan, while in the other regions (i.e., Nouvelle-Aquitanie, Auvergne-Rhône-Alpes, Provence-AlpesCôte d'Azur and Corse) the presence of windmills is quite marginal, also because of the poor wind conditions (Fig.6).

Unlike in the previous cases, the presence of WTs in the countries of southern Europe considered here (Portugal, Spain and Italy) is usually more concentrated geographically, so that their visual occurrence is limited to a small percentage of the territory (25\% in Portugal, and about $16 \%$ in Italy and Spain; Table 6). As in other EU countries (i.e. the UK, Netherlands, France, etc.), WPC grew rapidly in Portugal, so that wind supply now accounts for about the $24.2 \%$ of its electricity demand (Fraile \& Mbistrova, 2018). Feed-in tariff policy mechanism and public tenders for connection licenses are policy drivers to ensure the spread of wind farms (Peña et al., 2017), which are more concentrated (medium and high classes of density) in hilly northern and north-eastern distritos like Vizeu, Coimbra and Vila Real (Fig.7A). On the other hand, despite the current uncertain economic situation (Colmenar-Santos et al., 2015) which has seen a marked fall in investments in WPC since 2013 (Rosales-Asensio et al., 2019), Spain remains the second most important player in the wind energy sector in Europe. There, the largest market players (such as Iberdrola, Acciona Energía, EDP Renováveis, and Enel Green Power) who own most of the WTs (Ziegler et al., 2018), have mainly invested in large wind farms (AEE, 2017). For this reason, they often achieve quite high or very high density ${ }^{14}$, but the total area of land used for this purpose (including the high-density classes of WTS) is very limited (and does not even extend to $1.5 \%$ of the entire Spanish territory; see Table 6). Present in 16 out of 17 regions (with the exception of the Estremadura district), WTs are located both along the coast and inland, but mainly, of course, in the windiest geographical areas (Fig.5). As in Spain, after impressive growth in the early 2000s, growth in the wind market in Italy has slowed significantly since 2012, mainly due to uncertainties regarding the energy policies of the Italian government (Eurobserv'er, 2015). Applying our methodology, we estimate that there is an area of around $2,700 \mathrm{Km}^{2}$ where WT presence is widespread (values comprising the two highest density classes), mainly in southern Italy (Fig. 7B). In fact, the first wind farms (1999) were constructed in the most suitable areas (for windy conditions) along the Apennine ridges of southern Italy (mainly between Campania and Apulia regions). Only later (between 2008 and 2011) did their distribution become almost ubiquitous in the central-southern regions (i.e., Molise, Basilicata, Calabria, Sicily and Sardinia) (Mauro, 2011;

\footnotetext{
${ }^{14}$ In Spain, there are several areas (at least seven) with a very high WT density, for a total area of about $1,080 \mathrm{~km}^{2}$. The first is about $80 \mathrm{Km}$ at east of La Coruna in the north (the area with the maximum density in the study area). The second is on the Atlantic Ocean about $50 \mathrm{Km}$ at west of Santiago de Compostela. The third is close to the northern border with Portugal near Puebla de Sanabria. The fourth is near Burgos in the north of Spain. The fifth comprises two areas in the vicinity of Zaragoza in the northeast. The sixth is near Albacete in the region of Murcia in the southeast. The last one is close to Cadiz in the south (Fig. 7A).
} 
Mauro, 2013), sometimes - sadly - becoming a very lucrative business proposition for organized crime (Caneppele et al., 2013).
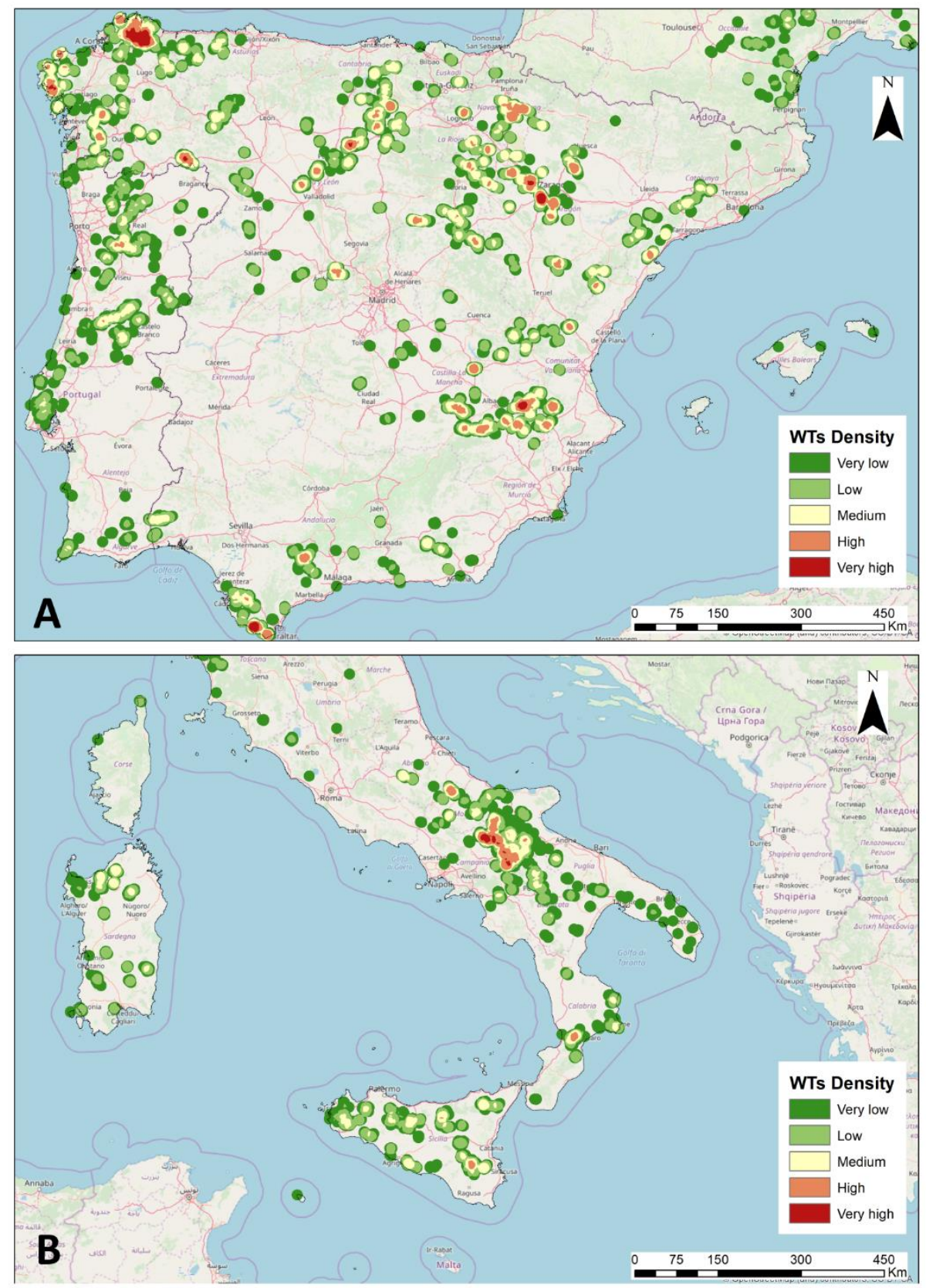

Figure 7. The spatial distribution of WTs in the Iberian Peninsula (A) and in central-southern Italy (B). Base Map: OSM.

\section{Discussion}

The European Directives regarding the development of RES set ambitious targets for each EU member state. As Wolsink (2007) has pointed out, "a complex set of variables rooted in institutional arrangements and social and political culture» [..] determine the success of specific policies, such as those concerning the wind sector. They are «the planning regime, the financial support system, the values attached to landscape quality and preservation, and the degree of local ownership of schemes to build wind farms". As this study shows, then, in the last two decades differing energy policies combined with differing sensitivities both to the environment and to the landscape have produced a different spatial distribution as regards a technology that we can now consider as being "mature", namely wind power. 


\begin{tabular}{|c|c|c|c|c|c|c|}
\hline Country & Wind & Main policy strategy & $\begin{array}{c}\text { Current WT } \\
\text { distribution } \\
\text { (National scale) }\end{array}$ & $\begin{array}{l}\text { Geography of } \\
\text { regions with higher } \\
\text { WT concentration }\end{array}$ & $\begin{array}{c}\text { Main local } \\
\text { positive effects }\end{array}$ & $\begin{array}{c}\text { Main local } \\
\text { negative effects }\end{array}$ \\
\hline Belgium & Medium high & $\begin{array}{l}\text { Top-down approach; } \\
\text { Large scale energy } \\
\text { producers; } \\
\text { Support offshore }\end{array}$ & $\begin{array}{l}\text { Medium high } \\
\text { spread }\end{array}$ & $\begin{array}{l}\text { Highly industrialized } \\
\text { and urbanized } \\
\text { regions }\end{array}$ & $\begin{array}{l}\text { WT in strictly limited } \\
\text { (and scenically } \\
\text { unattractive) areas }\end{array}$ & $\begin{array}{l}\text { Low benefits to local } \\
\text { communities; } \\
\text { Local opposition }\end{array}$ \\
\hline Denmark & Very high & $\begin{array}{l}\text { Pioneer country; } \\
\text { Bottom-up approach; } \\
\text { Small power plants; } \\
\text { Repowering / re-siting; } \\
\text { Support offshore }\end{array}$ & $\begin{array}{l}\text { Very high spread; } \\
\text { In some case, also } \\
\text { high concentration }\end{array}$ & $\begin{array}{l}\text { Peripheral rural } \\
\text { areas in the } \\
\text { nearshore regions of } \\
\text { the northwest; } \\
\text { Sparsely populated } \\
\text { areas }\end{array}$ & $\begin{array}{l}\text { Job opportunities in } \\
\text { domestic wind } \\
\text { companies; } \\
\text { Local ownership } \\
\text { (power cooperatives) } \\
\text { A new form of } \\
\text { tourism? }\end{array}$ & $\begin{array}{l}\text { Possible alteration of } \\
\text { aesthetic of the } \\
\text { landscape; } \\
\text { Increasing local } \\
\text { opposition to new } \\
\text { wind energy projects }\end{array}$ \\
\hline France & $\begin{array}{l}\text { Medium } \\
\text { (patchy } \\
\text { availability) }\end{array}$ & $\begin{array}{l}\text { Late development; } \\
\text { “Mixed approach", meaning } \\
\text { hierarchical 'siting'; } \\
\text { Support offshore }\end{array}$ & $\begin{array}{l}\text { Low spread; } \\
\text { Patchy distribution }\end{array}$ & $\begin{array}{l}\text { Hilly regions in the } \\
\text { northeast of the } \\
\text { Country and } \\
\text { "around" the } \\
\text { metropolitan area of } \\
\text { Paris; } \\
\text { Mountain areas of } \\
\text { Occitan }\end{array}$ & $\begin{array}{l}\text { Aesthetic preservation } \\
\text { of the landscape; } \\
\text { Job opportunities in } \\
\text { absence of leading } \\
\text { French turbine } \\
\text { manufacturers; } \\
\text { High tax revenues for } \\
\text { involved municipalities }\end{array}$ & $\begin{array}{c}\text { Conflict of interest of } \\
\text { mayors }\end{array}$ \\
\hline Germany & Medium high & $\begin{array}{l}\text { Great attention to this } \\
\text { issue; } \\
\text { Careful planning; } \\
\text { Bottom-up approach; } \\
\text { Small power plants; } \\
\text { Repowering; } \\
\text { Support offshore }\end{array}$ & $\begin{array}{l}\text { High spread; } \\
\text { In some cases, } \\
\text { very high WT } \\
\text { concentration }\end{array}$ & $\begin{array}{l}\text { Rural regions along } \\
\text { coastline; } \\
\text { Some internal areas } \\
\text { in the central and } \\
\text { eastern regions }\end{array}$ & $\begin{array}{l}\text { Job opportunities in } \\
\text { domestic wind } \\
\text { companies; } \\
\text { Local ownership } \\
\text { (power cooperatives); } \\
\text { A new form of } \\
\text { tourism? }\end{array}$ & $\begin{array}{l}\text { Possible alteration of } \\
\text { aesthetic of the } \\
\text { landscape }\end{array}$ \\
\hline Ireland & Very high & $\begin{array}{l}\text { Late development } \\
\text { Currently great attention to } \\
\text { wind energy; } \\
\text { Top-down approach }\end{array}$ & $\begin{array}{l}\text { Medium-low } \\
\text { spread }\end{array}$ & $\begin{array}{l}\text { Sparsely populated } \\
\text { hilly or mountain } \\
\text { moorland }\end{array}$ & $\begin{array}{l}\text { Recent growth of RES } \\
\text { cooperatives }\end{array}$ & $\begin{array}{l}\text { Limited job-creation } \\
\text { and low local benefits; } \\
\text { Increasing local } \\
\text { opposition to new } \\
\text { wind energy projects }\end{array}$ \\
\hline Italy & Medium-low & $\begin{array}{l}\text { Late development; } \\
\text { Unclear energetic planning; } \\
\text { Top-down approach; } \\
\text { Great involvement of } \\
\text { foreigners big companies }\end{array}$ & $\begin{array}{l}\text { Low spread, but } \\
\text { very high } \\
\text { concentration in } \\
\text { southern regions }\end{array}$ & $\begin{array}{l}\text { Internal low-density } \\
\text { rural areas (mainly } \\
\text { mountain) }\end{array}$ & $\begin{array}{l}\text { Job opportunities; } \\
\text { Limited landscape with } \\
\text { great aesthetic impact } \\
\text { (only in some small } \\
\text { areas of the country } \\
\text { with high WT } \\
\text { concentration) }\end{array}$ & $\begin{array}{l}\text { Low revenues for the } \\
\text { municipalities involved; } \\
\text { Negative externalities } \\
\text { consequences; } \\
\text { Sense of alienation } \\
\text { from future prospects; } \\
\text { Criminal infiltration }\end{array}$ \\
\hline Vetherlands & $\begin{array}{l}\text { Medium- } \\
\text { high }\end{array}$ & $\begin{array}{l}\text { Top-down approach; } \\
\text { Frequent changes in } \\
\text { subsidy scheme } \\
\text { Small power plants; } \\
\text { Support offshore }\end{array}$ & $\begin{array}{l}\text { Medium high } \\
\text { spread }\end{array}$ & $\begin{array}{l}\text { Rural and industrial } \\
\text { areas along coast } \\
\text { (often along dykes) }\end{array}$ & $\begin{array}{l}\text { Maximum use of wind } \\
\text { resource; } \\
\text { Very limited use of } \\
\text { agricultural land; } \\
\text { Recent growth of RES } \\
\text { cooperatives }\end{array}$ & $\begin{array}{l}\text { Possible alteration of } \\
\text { aesthetic of the } \\
\text { landscape; } \\
\text { Permanent local } \\
\text { opposition }\end{array}$ \\
\hline Portugal & Medium & $\begin{array}{l}\text { Late development; } \\
\text { Very favorable policy; } \\
\text { Centralized planning } \\
\text { Top-down approach }\end{array}$ & $\begin{array}{l}\text { Medium low } \\
\text { spread (mainly in } \\
\text { northern and } \\
\text { central regions) }\end{array}$ & $\begin{array}{l}\text { Internal rural areas } \\
\text { (mainly hilly) }\end{array}$ & $\begin{array}{c}\text { Aesthetic impact } \\
\text { limited to small areas } \\
\text { with big WT } \\
\text { concentration; } \\
\text { High direct benefit to } \\
\text { municipal authorities }\end{array}$ & $\begin{array}{l}\text { Sense of alienation } \\
\text { from future prospects; } \\
\text { Latent local opposition }\end{array}$ \\
\hline Spain & $\begin{array}{l}\text { Medium- } \\
\text { high } \\
\text { (patchy } \\
\text { availability) }\end{array}$ & $\begin{array}{l}\text { Very favorable policy; } \\
\text { Centralized planning } \\
\text { Top-down approach; } \\
\text { Big wind farms } \\
\text { Repowering }\end{array}$ & $\begin{array}{l}\text { Low spread but } \\
\text { very high } \\
\text { concentration in } \\
\text { several areas of } \\
\text { the country }\end{array}$ & $\begin{array}{l}\text { Heterogeneous } \\
\text { inland (mountains, } \\
\text { hilly or lowland } \\
\text { areas); } \\
\text { mainly in rural and } \\
\text { sparsely inhabited } \\
\text { areas }\end{array}$ & $\begin{array}{l}\text { Aesthetic impact } \\
\text { limited only to small } \\
\text { areas with big WT } \\
\text { concentration } \\
\text { Job opportunities in a } \\
\text { new industrial sector } \\
\text { (domestic industry) } \\
\text { Local benefits for rural } \\
\text { communities }\end{array}$ & $\begin{array}{l}\text { Low local community } \\
\text { participation in the } \\
\text { planning and } \\
\text { implementation of } \\
\text { wind farms }\end{array}$ \\
\hline $\begin{array}{l}\text { United } \\
\text { Kingdom }\end{array}$ & Very high & $\begin{array}{l}\text { Late development; } \\
\text { Frequent changes to } \\
\text { policies and policy; } \\
\text { Top-down approach (mainly } \\
\text { for bigger plants) } \\
\text { Re-powering; } \\
\text { Great support to offshore }\end{array}$ & Medium spread & $\begin{array}{l}\text { Mainly in sparsely } \\
\text { populated inland } \\
\text { areas, often } \\
\text { mountainous or hilly } \\
\text { moorland }\end{array}$ & $\begin{array}{l}\text { Aesthetic impact } \\
\text { limited only to small } \\
\text { areas with big WT } \\
\text { concentration }\end{array}$ & $\begin{array}{l}\text { Low benefits for local } \\
\text { communities }\end{array}$ \\
\hline
\end{tabular}

Table 7. Overview of our results in comparison with the wind resource and main policy strategies. 
Table 7 uses the most recent literature on the subject and attempts to summarize the main political strategies and their negative/positive effects as regards WT spatial distribution in the ten countries examined (Table 7). Although we cannot claim to be exhaustive (given the variety of landscapes involved), we have also tried to identify the geographical features common to 'windscapes'. For each country, we compared: wind speed classified roughly on the map in Figure 5 and in Table 6); main wind power policies/strategies in recent decades; the resulting spatial distribution of WT (classified roughly on the map in Figure 4); main geographical features of the region with larger number of WT; main positive and negative effects at the local level (deriving from our analysis, but also from the policies adopted by each EU member state). Given the scale (national), these are obviously just general indications useful for a comparison between the countries examined.

The great attention that Germany and Denmark have always paid to wind power development has led to clear policies in this energy sector by the respective central governments. The adoption of the "foot in the door" policy (Jobert et al., 2007; Maegaard, 2014) is probably what produced the present very widely spread distribution of WT in these two countries. This policy is based on the idea that small wind parks with a few large turbines are more acceptable than large wind parks with many small turbines (Thayer \& Freeman, 1987; Wolsink \& van de Wardt, 1989). Besides, despite having central planning, Germany and Denmark are the two countries which have offered most support to bottom-up policies by encouraging the development of a strong network of local cooperatives (Bawens et al., 2016). This has created job opportunities ${ }^{15}$ in the leading domestic wind companies (Lewis \& Wiser, 2007), sometimes also in the more depressed regions, such as the "rotten banana" ${ }^{16}$ area of Denmark (Laursen \& Anderson, 2011). Combined with the local economic benefits (mainly fees for landowners and tax revenues for municipalities), these positive effects probably make up for the high aesthetic visual impact of WT in the German and Danish windscapes. However, current repowering policies (Miles \& Jensen, 2004; Ziegler et al., 2018) are very expensive, mainly due to the cost of new wind technologies. These charges and the recent remuneration methods, heavily influenced by auctions (Maegaard, 2014), tend to undermine the RES cooperative system, giving rise to mounting local opposition to the new wind energy projects.

Although the political approach in France is more hierarchical, there too, local communities are given an important role, on the basis of a perspective of "siting policy" ${ }^{17}$ (Wolsink, 1996). In fact, in order to build a new wind farm, the approval of the local mayor and the city council is needed, "who act in the interest of the local inhabitants» (Nadaï \& Labussière, 2009), as well as rather long waiting times (Enevoldsen \& Sovacool, 2016). In this way, local communities are ensured the preservation of their landscapes of greater aesthetic value. This has been achieved without negative effects on the important job opportunities offered by the sector, which is a great result considering the absence of any leading French turbine manufacturers for onshore wind power (ADEME, 2017). The policies of neighbouring Belgium and the Netherlands, on the other hand, are characterized by a more top-down approach. In Belgium, electricity generation is controlled by one national company (Bawens et al., 2016) and the wind power sector is dominated by a very limited number of big players. An unequal distribution of costs and benefits (more favorable for the large scale energy producers) might partially explain the protests of local communities against wind farms (Pepermans \& Loots, 2013), despite the fact that the turbines are often concentrated in scenically unattractive spaces such as, for example, industrial areas or ports. Dutch policies, on the other hand, have often been seen as being too variable, given the frequent changes in the support system for RES. For this reason, the political system is considered to be unreliable in this matter (Breukers, 2007), and this has had a serious impact on

\footnotetext{
15 In 2017, about 160,000 jobs are estimated to be connected to the wind energy sector in Germany, while the number for Denmark is over 30,000. Other countries with a high number of jobs connected (directly and indirectly) to the wind sector are Italy $(26,000)$, Spain (almost 22,500) and France $(19,000)$ (IEA Wind, 2018).

16 The "rotten banana" is the term coined to describe the western part of Denmark, because in recent years it has become increasingly rural and has seen a decline in population (Laursen \& Anderson, 2011).

17 The expression "siting policy" describes "a policy that deals with local issues related to the siting of wind power infrastructures» (Nadaï, 2007).
} 
investment in Dutch wind power (Niesten et al., 2018). These circumstances have reinforced the persistent and strong internal opposition (van Os et al., 2014). In recent years, however, there have been some changes: further investments have been made available to support RES cooperatives (van der Schoor \& Scholtens, 2015) and new job opportunities have come from the mid-sized turbine manufacturing sector, where Holland and Belgium are emerging leaders (IEA Wind, 2018).

In recent years, the UK wind market, too, has been characterized by relatively frequent changes to policy and policy instruments, and this has sometimes created situations of uncertainty for investors (Keay, 2016). This approach to wind support policies has resulted in the involvement of large private companies, while local ownership and the local communities have been marginalized (Warren \& McFayden, 2010). However, it is important to stress the great differences in procedure for obtaining planning permission, depending on the size of the wind farm, divided into three main groups: small turbines, wind farms up to $50 \mathrm{MW}$ and large wind farms over $50 \mathrm{MW}^{18}$. Only permits for those over $50 \mathrm{MW}$ are issued by central government and, in any case, local authorities still have "the final say". This provides local communities with a veto with which to block the development of more unpopular or controversial wind farms. As a result, in the period 1991-2017 more than $50 \%$ of proposed wind projects have been rejected or abandoned, the highest rate for a renewable energy technology in Great Britain (Harper et al., 2019). Although significantly limited by the lack of OSM data (almost -30\% when compared to the official data; see Section 5.1), our geographical analysis of WT distribution showed a medium spread of small wind farms. Whereas central and southern Scotland contains the biggest wind farms in the EU, mainly in sparsely populated inland areas (mostly hilly or mountain moorlands). In the face of a fairly limited visual impact, then, the absence of UK manufacturers of onshore turbines and the simultaneous presence of a very small number of multi-national companies controlling the sector means relatively few economic benefits to host communities (Munday et al., 2011). Ireland's heavy dependence on imported energy supplies has led to a great focus on wind power (Rourke et al., 2009), which is bound to play a key role in the Irish energy sector given the country's excellent wind conditions. As in the UK, this late attention to wind is probably due to the decline in the supply of traditional sources such as oil and gas coming from neighbouring Great Britain (Devlin et al., 2017). However, Ireland's policies too mainly offer support to private developers (Warren et al., 2005). In recent years, many small and medium-sized companies have installed small-scale auto-production WT units in response to the government energy policies encouraging businesses to generate their own electricity for onsite consumption. This strategy is not of great useful to the national energy system (Kealy, 2017), however, given the considerably long waiting times and the heavy costs involved in getting connected to the national electricity grid (ENVE, 2018). Although wind power is generally well accepted in Ireland, low local benefits and limited job-creation have been giving rise to growing local opposition (Brennan \& van Reesburg, 2017). Perhaps also for these reasons, the central government has offered generous support to the current rapidly growing industry of communityowned RES (ENVE, 2018).

In Portugal, Spain and Italy, generous government subsidies and the limited (and at times non-existent) involvement of the local population in the planning processes for new WT plants have encouraged the presence of large electricity companies (Delicado et al., 2016; ANEV, 2018), meaning that control is concentrated within a few energy corporations (Delicado et al., 2014). This may well be why the spatial pattern of WT distribution is different in these countries compared to those of northern Europe: as we said above, the WT are mainly concentrated in a few specific areas, reducing their visual impact to small portions of territory and maximizing the use of wind where it is supposedly strongest. However, this strategy might give rise to a sense of alienation on the part of the local community (mainly regarding future territorial prospects), which could result in opposition to new WT farms. In Portugal, for instance, just five companies hold about $76 \%$ of the market share and there are no community-owned wind farms (Silva \& Delicado, 2017). For this reason, high direct benefits ( $2.5 \%$ of the annual revenue of wind farms) are recognized to municipal

\footnotetext{
${ }^{18}$ Small wind turbines are treated as "permitted development" (the highest part of the turbine must not exceed $11 \mathrm{~m}$ ). while for the wind farms up to $50 \mathrm{MW}$, permission must be obtained from the local planning authority.
} 
authorities with WT farms within their territory, also to soften any latent local opposition (Delicado et al., 2016). In Spain, to, most WTs are owned by large market players, but they are often national companies (such as Iberdrola, Acciona Energía or EDP Renováveis; Ziegler et al., 2018). The creation of a new industrial sector with a high employment rate and a high fee for landowners as tax revenues for the municipalities have actually contributed to the development of several of the country's rural areas rural areas (Galdos Urrutia \& Madrid Ruiz, 2009), and these favorable conditions have obviously enhanced levels of social acceptance of wind power in Spain, but since 2012, government decisions to make the market more economically sustainable have put a brake on private investment in this sector. In any case, the significant growth in wind farms which occurred mainly in the period 2000-2010 explains the highest WT concentration in the whole study area. Large wind plants are currently distributed in Spain in heterogeneous landscapes (mountains, hilly or lowland areas), and mainly in rural and sparsely inhabited areas. Finally, in the case of Italy, unclear government policies on energy issues and the strong presence of large foreign operators (ANEV, 2018) have resulted in a low level of involvement on the part of local communities in decisions regarding land-use. Other negative external factors (such as uneven road surfaces after new wind farms have been built and the significant visual impact of WT, often in unspoiled, natural environments), as well as the current conflicting policies (Caporale \& De Lucia, 2015) sometimes resulting in reduced tax revenues for the municipalities involved have given rise to new debates about wind power. As a consequence, levels of social acceptance are usually low, despite the significant job opportunities offered by the wind sector in the less affluent regions of southern Italy.

\section{Final remarks}

In the last two decades, the remarkable growth of RES (mainly photovoltaic and wind energy) has sometimes led to changes in the landscapes, giving rise to a discussion on their 'real' sustainability. The main aim of this paper is to "photograph" the current situation regarding WTs in the ten EU countries with the biggest wind energy sector. To this end, we used the free maps of OSM as our main dataset. Once again, the OSM participative cartography has shown its good reliability: although the number is underestimated, the VGI of OSM actually map more than 75,000 WTs, almost $90 \%$ of those present. Being able to know the exact geographical position of each WT made it possible to map (and count) those territories with a high concentration of these modern windmills.

Overall, in the entire study area, over $10,000 \mathrm{Km}^{2}$ of land (an area the same size as Lebanon) is visually occupied by a high presence of WTs (meaning more than 100 WTs in a circle area with a radius of $10 \mathrm{Km}$ ). However, different situations emerged when the various countries were compared, mostly as a result of the main strategic policies adopted in the wind power sector in recent decades. To the north, Germany, Denmark, the Netherlands and Belgium have seen a massive spreading of WTs throughout their territory. The governments of these countries have tended to support the development of the wind sector, sometimes also with participatory forms of enterprise (such as cooperatives). Using a GIS approach, we mapped a high density of WTs in several parts of northern and central Germany (i.e., Schleswig-Holstein, Lower Saxony, North Rhine-Westphalia and Brandenburg), and in Denmark (Nordjylland), the Netherlands (Flevoland) and finally, in the UK (the north-west). On the other hand, despite the economic and/or political uncertainties the main market players continue to play a key role in the wind markets of Spain and Italy, where most of the investment has been in large wind farms in the windiest landscapes. In the Mediterranean countries considered, then (Spain, Portugal and Italy), WTs are mainly concentrated only in the few windiest areas. A high concentration of WTs was recorded in several regions of Spain (Galicia, Castile Y Leon, Aragon, Castile La Mancha and Andalusia) and in southern Italy (Campania, Apulia, Calabria and Sicily).

In the light of these findings, then, can these regions be defined as 'windscapes'? As our analysis demonstrates, they are usually to be found in sparsely populated rural areas (with the exception of Belgium), sometimes in less-advantaged regions (for example in Italy and Denmark). For this reason, wind power could 
represent a social rescue opportunity, despite the fact that the communities living in these internal areas (Verburg et al., 2010) often feel excluded, as in Portugal or in Italy.

Actually, the truth is that the concept of landscape is probably much more complex, especially in geographical terms. In itself, it is unlikely that an unusually high density of WTs is a sufficient reason to describe these areas as windscapes. Undoubtedly, despite their visual impact being one of the most criticized aspects of wind energy, if we imagine the landscape as a theatre (Turri, 1998), the modern windmills have become "distinctive elements of the territorial organization" such a familiar feature of these regions. Therefore, WT represent a sort of icon of post-industrial society of these emerging landscapes of carbon neutrality that we must learn to see with a different perspective (Selman, 2010). It cannot be denied that in a world where energy demand is constantly increasing, wind farms are far less impactful as industrial areas than traditional fossil-based power stations, which usually cause significant environmental pollution (atmospheric, water and soil) of the surrounding area.

In conclusion, this paper is the first estimation on a continental scale of the current situation as regards wind power. It also offers a methodological basis with which to evaluate the visual impact of the WTs already present in a given area. A careful planning of how our wind resources are exploited (especially when WTs are already present) is the key to managing to respect the needs of local populations and guaranteeing the sustainability of this RES. For this reason, it might be very useful to apply this methodology on a national or regional scale in order to make a preliminary assessment of the wind-carrying capacity of a given area.

\section{Bibliography}

ADEME (Agence de l'Environnement et de la Maîtrise de l'Energie), (2017). Analysis of the French wind power sector: overview, prospective analysis and strategy. ADEME Editions, Angers Cedex. www.ademe.fr Accessed 15 April 2019.

Almendros-Jemenéz, J.M., \& Becerra-Terón, A. (2018). Analyzing the Tagging Quality of the Spanish OpenStreetMap. ISPRS, International Journal of Geo-Information, 7, 323-349. https://doi.org/10.3390/ijgi7080323

Andriosopoulos, K., \& Silvestre, S. (2017). French energy policy: A gradual transition. Energy Policy, 106, 376381. https://doi.org/10.1016/i.enpol.2017.04.015

Arantegui, R.L., \& Jäger-Waldau, A. (2018). Photovoltaics and wind status in the European Union after the Paris Agreement. Renewable and Sustainable Energy Reviews, 81, 2460-2471. https://doi.org/10.1016/j.rser.2017.06.052

Asociación Empresaria Eolica (AEE). Wind Energy in Spain (2017). https://www.aeeolica.org/en/about-windenergy/wind-energy-in-spain Accessed 22 July 2018.

Instituto de Ciência e Inovação em Engenharia Mecânica e Engenharia Industrial (INEGI), \& Associação Portuguesa de Energias Renováies (APREN), (2018). Parques Eólicos em Portugal. APREN: Lisboa (PT). https://www.apren.pt/contents/documents/wind-power-2017-2642.pdf Accessed 20 July 2018.

Association pour la Promotion des Energies Renouvelables (APERe). Observatoire éolien. (2018). http://www.apere.org/observatoire-eolien Accessed 20 June 2018.

Associazione Nazionale Energia del Vento (ANEV), (2018). Rapporto 2018. ANEV: Roma. https://www.anev.org/wp-content/uploads/2018/06/Anev brochure 2018NEWweb.pdf Accessed 23 July 2018.

Barlas, E., Zhu, W.J., Shen, W.Z., Dag, K.O., \& Moriarty, P. (2017). Consistent modelling of wind turbine noise propagation from source to receiver. The Journal of the Acoustical Society of America, 142, 3297-3310. https://doi.org/10.1121/1.5012747 
Bauwens, T., Gotchev, B., \& Holstenkamp, L. (2016). What drives the development of community energy in Europe? The case of wind power cooperatives. Energy Research \& Social Science, 13, 136-147. http://doi.org/10.1016/i.erss.2015.12.016

Bennet, J. (2010). OpenStreetMap. Be your own Cartographer. PACKT Publishing: Birmingham (UK).

Betakova, V., Vojar, J., \& Skenicka, P. (2015). Wind turbines location: How many and how far? Applied Energy, 151, 23-31. https://doi.org/10.1016/j.apenergy.2015.04.060

Bishop, I.D. (2002). Determination of threshold of visual impact: the case of wind turbines. Environment and Planning B: Planning and Design, 29, 707-718. https://doi.org/10.1068/b12854

Borrough, P.A. (1990). Principles of Geographical Information Systems for Land Resources Assessment. Oxford University Press: Oxford (UK).

Brennan, N., \& van Reesburg, T.M. (2017). Wind farm externalities and public preferences for community consultation in Ireland: A discrete choice experiments approach. Energy Policy, 94, 355-365. https://doi.org/10.1016/i.enpol.2016.04.031

Breukers, S. C. (2007). Changing institutional landscapes for implementing wind power: a geographical comparison of institutional capacity building: The Netherlands, England and North Rhine-Westphalia. Amsterdam: Amsterdam University Press.

Caneppele, S., Riccardi, M., \& Standridge, P. (2013). Green energy and black economy: mafia investments in the wind power sector in Italy. Crime Law Social Change, 59, 319-339. https://doi.org/10.1007/s10611$\underline{013-9418-1}$

Caporale, D., \& De Lucia, C. (2015). Social acceptance of on-shore wind energy in Apulia Region (Southern Italy). Renewable and Sustainable Energy Reviews, 52, 1378-1390. https://doi.org/10.1016/j.rser.2015.07.183

Carlos, H.A., Shi, X., Sargent, J., Tanski, S., \& Berke E.M. (2010). Density estimation and adaptive bandwidths: A primer for public health practitioners. International Journal of Health Geographics, 9:39. https://doi.org/10.1186/1476-072X-9-39

Colmenar-Santos, A., Campíñez-Romero, S., Pérez-Molina, C., \& Mur-Pérez, F. (2015). Repowering: An actual possibility for wind energy in Spain in a new scenario without feed-in-tariffs. Renewable and Sustainable Energy Reviews, 41, 319-337. https://doi.org/10.1016/i.rser.2014.08.041

Commission for the Environment, Climate change and Energy (ENVE) (2018). Models of Local Energy Ownership and the Role of Local Energy Communities in Energy Transition in Europe. European Committee for the Regions. Bruxelles. doi:10.2863/603673

Curran, K., Crumlish J., \& Fisher G. (2012). OpenStreetMap. International Journal of Interactive Communication System and Technology, 2(1), 69-78. DOI: 10.4018/ijicst.2012010105

Daniel, TC. (2001). Whither scenic beauty? Visual landscape quality in the 21st century. Landscape Urban Plan, 54, 267-281. https://doi.org/10.1016/S0169-2046(01)00141-4

Danish Energy Agency (DEA). Master Data register of wind turbines. (2018). https://ens.dk/en/ourservices/statistics-data-key-figures-and-energy-maps/overview-energy-sector Accessed 25 may 2018.

De Agostini (2000). Calendario Atlante De Agostini. Istituto Geografico De Agostini: Novara (Italy).

Dent, C.M. (2013). Wind energy development in East Asia and Europe. Asian Europe Journal, 11, 211-230. https://doi.org/10.1007/s10308-013-0360-8

Deutsche WindGuard. Status of land-based wind energy development in Germany 2017. Deutsche WindGuard GmbH, Varel, Germany. (2018). https://www.windguard.com/year-2017.html Accessed 15 July 2018.

Delicado, A., Junqueira, L., Fonseca, S., Truninger, M., Silva, L., Horta, A., \& Figueiredo, E. (2014). Not in Anyone's Backyard? Civil Society Attitudes towards Wind Power at the National and Local Levels in Portugal. Science \& Technology Studies, 27 (2), 49-71. 
Delicado, A., Figueiredo, E., \& Silva, L. (2016). Community perceptions of renewable energies in Portugal: impacts on environment, landscape and local development. Energy Research \& Social Science, 13, 84-9. https://doi.org/10.1016/j.erss.2015.12.007

Devlin, J., Li, K., Higgins, P., \& Foley, A. (2017). Gas generation and wind power: A review of unlikely allies in the United Kingdom and Ireland. Renewable and Sustainable Energy Reviews, 70, 757-768. https://doi.org/10.1016/i.rser.2016.11.256

Enevoldsen, P., Sovacool, B.K. (2016). Examining the social acceptance of wind energy: Practical guidelines for onshore wind project development in France. Renewable and Sustainable Energy Reviews, 53, 178-184. https://doi.org/10.1016/j.rser.2015.08.041

Eurobserv'er, (2015). Wind Energy Barometer, $11^{\text {th }}$. Eurobserver: Paris (FR).

European Environment Agency (EEA), (2014). Energy support measures, case study - The Netherlands. Energy Support and Innovation: Brussels (B). https://www.eea.europa.eu/publications/energy-supportmeasures/case-study-the-netherlands

Evans, A., Strezov, V., \& Evans, T.J. (2009). Assessment of sustainability indicators for renewable energy technologies. Renewable and Sustainable Energy Review, 13, 1082-1088. https://doi.org/10.1016/j.rser.2008.03.008

Favretto, A. (2014). Scale factor and image resolution: some cartographic considerations. Journal of Research and Didactics in Geography (J-READING), 1, 3, 15-20. DOI: 10.4458/3253-03

Foley, A.M., O' Gallachóir, B.P., McKeogh, E.J., Milborrow, D., \& Leahy, P.G. (2013). Addressing the technical and market challenges to high wind power integration in Ireland. Renewable and Sustainable Energy Review, 19, 692-703. https://doi.org/10.1016/j.rser.2012.11.039

Fraile D., \& Mbistrova, A. (2018). Wind in power 2017. Annual combined onshore and offshore wind energy statistics. WindEurope: Brussels. https://windeurope.org/wp-content/uploads/files/about-wind/statistics/ France Energie Eolienne (FEE) (2017). Observatoire de l'éolien 2017. https://fee.asso.fr/ Accessed 15 July 2018.

Fthenakis, V., \& Kim, H. C. (2009). Land use and electricity generation: A life-cycle analysis. Renewable and Sustainable Energy Review, 19, 1465-1474. https://doi.org/10.1016/j.rser.2008.09.017

Galdos Urrutia, R., \& Madrid Ruiz, F.J. (2009). La energia eolica en Espana y su contribucion al desarrollo rural. Investigaciones Geográficas, 50, 93-108.

Goodchild, M.F. (2007). Citizen as sensors: the world of volunteered geography. GeoJournal, 69 (4), 211-221. https://doi.org/10.1007/s10708-007-9111-y

Harper, M., Anderson, B., James, P.A.B. , \& Bahaj, A.S. (2019). Onshore wind and the likelihood of planning acceptance: Learning from a Great Britain context. Energy Policy, 128, 954-966. https://doi.org/10.1016/j.enpol.2019.01.002

Hurtado, J.P., Fernández, J., Parrondo, J.L., \& Blanco, E. (2004). Spanish method of visual impact evaluation in wind farms. Renewable and Sustainable Energy Reviews, 8, 483-491. https://doi.org/10.1016/i.rser.2003.12.009

International Energy Agency (IEA) (2017, a). Renewables information: Overview. Paris: IEA. https://webstore.iea.org/renewables-information-2017-overview Accessed 12 September 2018.

International Energy Agency (IEA) (2017, b). Key world energy statistics. Paris: IEA. 2017. https://www.iea.org/publications/freepublications/publication/Accessed 15 September 2018.

International Energy Agency (IEA) Wind, (2018). Technologies, Collaboration Program, Annual Report. Washington: IEA. https://community.ieawind.org/publications/ar Accessed 5 May 2019.

International Energy Agency (IEA) Wind, (2016). 2015 Annual Report. https://www.seai.ie/resources/publications/IEA Wind Annual Report 2015.pdf Accessed 18 November 2018. 
Jallouli, J., \& Moureau, G. (2009). An immersive path-based study of wind turbines' landscape: A French case in Plouguin. Renewable Energy, 34, 2009, 597-607. https://doi.org/10.1016/j.renene.2008.05.036

Jobert, A., Laborgne, P., \& Mimler, S. (2007). Local acceptance of wind energy: Factors of success identified in French and German case studies. Energy Policy, 35, 2751-2760.

https://doi.org/10.1016/i.enpol.2006.12.005

Kaur, J., Singh, J., Shing Shera, S., \& Shing Rai, H. (2017). Systematic Literature Review of Data Quality within OpenStreetMap. International Conference on Next Generation Computing and Information Systems (ICNGCIS), 177-182.

Keay, M. (2016). UK energy policy - Stuck in ideological limbo? Energy Policy 94, 247-252. https://doi.org/10.1016/j.enpol.2016.04.022

Kealy, T. (2017). Stakeholder outcomes in a wind turbine investment; is the Irish energy policy effective in reducing GHG emissions by promoting small-scale embedded turbines in SME's? Renewable Energy, 101, 1157-1168. https://doi.org/10.1016/j.renene.2016.10.007

Knies, J., \& Gräfe A. (2011). Visibility analysis as a tool for regional planning in the context of "repowering" (wind-turbine upgrading). A transferable example for "North Sea Sustainable Energy Planning". Institute for Applied Photogrammetry and Geoinformatics: Oldenburg (Germany).

Laursen, L.H., \& Anderson, L. (2011). Differentiated decline in Danish outskirt areas. Spatial restructuring and citizen--based development in the village of Klokkerholm. Danish Journal of Geoinformatics and Land Management, 46(1), 96-113.

Lewis, J.I., \& Wiser, R.H. (2007). Fostering a renewable energy technology industry: An international comparison of wind industry policy support mechanisms. Energy Policy, 35, 1844-1857. https://doi.org/10.1016/i.enpol.2006.06.005

Lothian, A. (2008). Scenic of the visual effect of wind farms on south Australian Landscapes Geographical Research, 46 (2), 196-207. https://doi.org/10.1111/i.1745-5871.2008.00510.x

Maegaard, P. (2014). Towards Public Ownership and Popular Acceptance of Renewable Energy for the Common Good. In: P. Maegaard, A. Krenz \& W. Palz, eds. Wind Power for the World: International Reviews and Developments. Singapore: Pan Standford Publishing Pte. Ltd.

Maier, G. (2014). OpenStreetMap, The Wikipedia Map. Region, Vol. 1, n. 1, R3-R10.

Mauro, G. (2011). Renewable Energy and Virtual Worlds: the recent growth of wind farm in Italy. Poster session presentation at the RGS-IBG Annual International Conference 2011, Royal Geographical Society, London (UK).

Mauro, G. (2013). Criticità paesaggistiche indotte dalla recente crescita delle centrali eoliche in Italia, in G., Scanu (Ed.), Paesaggi Ambienti Culture Economie, La Sardegna nel Mondo Mediterraneo, (pp. 325-335), Patron Editore: Bologna (Italy).

Mauro, G., \& Lughi, V. (2017). Mapping land use impact of photovoltaic farms via crowdsourcing in the Province of Lecce (Southeastern Italy). Solar Energy, 155, 434-444. https://doi.org/10.1016/j.solener.2017.06.046

Miles, N., \& Jensen, A. (2004). Spatial Planning for Wind Energy: Lessons from the Danish Case. Roskilde Universitetscenter, Roskilde, Denmark. Available on: https://core.ac.uk/download/pdf/12514130.pdf Accessed 25 April 2019.

Michell, A. (1999). The ESRI Guide to GIS Analysis: Geographic patterns \& relationships. Vol. I. ESRI Press.

Mitchell, C., \& Connors, P. (2004). Renewable energy policy in the UK 1990-2003. Energy Policy, 32, 19351947. https://doi.org/10.1016/j.enpol.2004.03.016

Molina-Ruiz, J., Martínez-Sánchez, M.J., Pérez-Sirvent, C., Tudela-Serrano, M.L., \& García Lorenzo, M.L. (2011). Developing and applying a GIS-assisted approach to evaluate visual impact in wind farms. Renewable Energy, 36, 1125-1132. https://doi.org/10.1016/j.renene.2010.08.041 
Möller, B. (2006). Changing wind-power landscapes: regional assessment of visual impact on land use and population in Northern Jutland, Denmark. Applied Energy, 83, 477-494. https://doi.org/10.1016/j.apenergy.2005.04.004

Molnarova, K., Sklenicka, P., Stiborek, P., Svobodova, K., Salek, M., \& Brabec E. (2012). Visual preferences for wind turbines: location, number and respondent characteristics. Applied Energy, 92, 269-278. https://doi.org/10.1016/i.apenergy.2011.11.001

Munday, M., Bristow, G., \& Cowell, R. (2011). Wind farms in rural areas: How far do community benefits from wind farms represent a local economic development opportunity? Journal of Rural Studies, 27, 1-12. https://doi.org/10.1016/j.jrurstud.2010.08.003

Nadaï, A. (2007). "Planning", "siting" and the local acceptance of wind power: Some lessons from the French case. Energy Policy, 35, 2715-2726. https://doi.org/10.1016/j.enpol.2006.12.003

Nadaï, A., \& Labussière, O. (2009). Wind power planning in France (Aveyron), from state regulation to local planning. Land Use Policy, 26, 744-54. https://doi.org/10.1016/j.landusepol.2008.10.018

Nadaï, A., \& van der Horst, D. (2010). Introduction: Landscapes of Energies. Landscape Research, 35:2, 235257. https://doi.org/10.1080/01426390903557543.

Neis, P., \& Zielstra, D. (2014). Recent Developments and Future Trends in Volunteered Geographic Information Research: The Case of OpenStreetMap. Future Internet, 6, 76-106. https://doi.org/10.3390/fi6010076

Niesten, E., Jolink, A., \& Chappin, M. (2018). Investments in the Dutch onshore wind energy industry: A review of investor profiles and the impact of renewable energy subsidies. Renewable and Sustainable Energy Reviews, 81, 2519-2525. https://doi.org/10.1016/j.rser.2017.06.056

Pedersen, E., Hallberg, LR.-M., \& Waye, K.P. (2007). Living in the vicinity of wind turbines -A grounded theory study. Qualitative Research in Psychology, 4, 49-63. https://doi.org/10.1080/14780880701473409

Peña, I., Azevedo, L.I., \& Ferreira, L.A.F.M. (2017). Lessons from wind policy in Portugal. Energy Policy, 103, 193-202. https://doi.org/10.1016/j.enpol.2016.11.033

Pepermans, Y., \& Loots, I. (2013). Wind farm struggles in Flanders fields: A sociological perspective. Energy Policy, 59, 321-328. https://doi.org/10.1016/j.enpol.2013.03.044

Petrova, M.A. (2013). NIMBYism revisited: public acceptance of wind energy in the United States. Wiley interdisciplinary Review of Climate Change, 4, 575-601. https://doi.org/10.1002/wcc.250

Ramm, F., Topf, J., \& Chilton, S. (2011). OpenStreetMap. Using and Enhancing the Free Map of the World. UIT: Cambridge (UK).

Rosales-Asensio, E., Borge-Diez, D., Blanes-Peiró, J-J-, Pérez-Hoyos, A., \& Comenar-Santos, A. (2019). Review of wind energy technology and associated market and economic conditions in Spain. Renewable and Sustainable Energy Reviews, 101, 415-427. https://doi.org/10.1016/j.rser.2018.11.029

Rourke, F.O., Boyle, F., \& Reynolds, A. (2009). Renewable energy resources and technologies applicable to Ireland. Renewable and Sustainable Energy Reviews, 13, 1975-1984. https://doi.org/10.1016/j.rser.2009.01.014

Saidur, S., Islam, M.R., Rahim, N.A., \& Solangi, K.H. (2010). A review on global wind energy policy. Renewable and Sustainable Energy Reviews, 14, 1744-1762. https://doi.org/10.1016/j.rser.2010.03.007

Saidur, S., Rahim, N.A., Islam, M.R., \& Solangi K.H. (2011). Environmental impact of wind energy. Renewable and Sustainable Energy Reviews, 15, 2423-2430. https://doi.org/10.1016/i.rser.2011.02.024

Sawyer, S., Liming, Q., \& Fried, L. (2018). Global Wind Report. Annual Market Update 2017. Brussels: Global Wind Energy Council (GWEC). https://gwec.net/publications/global-wind-report-2/ Accessed 14 November 2018.

Selman, P. (2010). Learning to Love the Landscapes of Carbon-Neutrality. Landscape Research, 35 (2), 157171. https://doi.org/10.1080/01426390903560414 
Shang, H., \& Bishop, I.D. (2000). Visual threshold for detection, recognition and visual impact in landscape settings. Journal of Environmental Psychology, 20, 125-140. https://doi.org/10.1006/jevp.1999.0153

Silva, L., \& Delicado, A. (2017). Wind farms and rural tourism: A Portuguese case study of residents' and visitors' perceptions and attitudes. Moravian Geographical Reports, 25 (4), 248-256. 10.1515/mgr-2017-0021 Sklenicka, P., \& Zohuar, J. (2018). Predicting the visual impact of onshore wind farms via landscapes indices: A method for objectivizing planning and decision processes. Applied Energy, 209, 445-454. https://doi.org/10.1016/j.apenergy.2017.11.027

Sullivan, R.G., Kirchler, L.B., Lahti, T., Roché, S., Beckman, K., Cantwell, B., \& Richmond, P. (2014, May). Wind Turbine Visibility and Visual Impact Threshold Distances in Western Landscapes. Paper session presentation at the 37th Annual Conference of National Association of Environmental Professionals (NEAP), Portland, Oregon (US).

Thayer, R.L., \& Freeman, C., (1987). Altamont: public perceptions of a wind energy landscape. Landscape and Urban Planning, 14, 373-398. https://doi.org/10.1016/0169-2046(87)90051-X

Torres Sibille, A.d.C., Cloquell-Ballester, V.A., Cloquell-Ballester, V.A., \& Darton R. (2009). Development and validation of a multicriteria indicator for the assessment of objective aesthetic impact of wind farms. Renewable and Sustainable Energy Reviews, 13, 40-66. https://doi.org/10.1016/j.rser.2007.05.002 Troen, I., \& Petersen, E. (1989). European Wind Atlas. Ris $\varnothing$ National Laboratory: Roskilde (DK).

Tsoutsos, T., Tsouchlaraki, A., Tsiropoulos, M., \& Serpetsidakis, M. (2009). Visual impact evaluation of a wind park in a Greek island. Applied Energy, 86, 546-553. https://doi.org/10.1016/i.apenergy.2008.08.013

Turri, E. (1998). Il paesaggio come teatro. Dal territorio vissuto al territorio rappresentato. Marsilio Editore: Venezia (Italy).

United Kingdom Wind Energy Database (UKWED). Wind Energy Statistics. (2018). https://www.renewableuk.com/page/UKWEDhome Accessed 22 July 2018.

University of Newcastle (2002). Visual assessment of windfarms: best practice. Commissioned report F01AA303A. Scottish Natural Heritage: Inverness, Scotland.

van der Schoor, T., \& Scholtens, B. (2015). Power to the people: Local community initiatives and the transition to sustainable energy. Renewable and Sustainable Energy Reviews, 43, 666--675. https://doi.org/10.1016/j.rser.2014.10.089

van Os, H.W.A., Herber, R., \& Scholtens, B. (2014). Not Under Our Back Yards? A case study of social acceptance of the Northern Netherlands CCS initiative. Renewable and Sustainable Energy Reviews, 30, 923942. https://doi.org/10.1016/j.rser.2013.11.037

Verburg, P.H., van Berkel, D.B., van Doorn, A.M., van Eupen, M., \& van den Heiligenberg, H.A.R.M. (2010). Trajectories of land use change in Europe: a model-based exploration of rural futures. Landscape Ecology, 25, 217-232. https://doi.org/10.1007/s10980-009-9347-7

Vissering, J., Sinclair, M., \& Margolis, A. (2011). A visual impact assessment process for wind energy projects. Clean Energy States Alliance (CESA): Montpelier, Vermont (US).

Wang, S., \& Wang, S. (2015). Impacts of wind energy on environment: A review. Renewable and Sustainable Energy Reviews, 49, 437-443. https://doi.org/10.1016/j.rser.2015.04.137

Warren, C.R., Lumsden, C., O'Dowd, S., \& Birnie R.V. (2005). 'Green on Green': public perceptions of wind power in Scotland and Ireland. Journal of Environmental Planning and Management, 48, 6, 853-875. https://doi.org/10.1080/09640560500294376

Warren, C., \& McFayden, M. (2010). Does community ownership affect public attitudes to wind energy? A case study from South-West Scotland. Land Use Policy, 27 (2), 204-213. https://doi.org/10.1016/j.landusepol.2008.12.010

Wolsink, M. (1996). Dutch wind power policy: stagnating implementation of renewables. Energy Policy, 24 (12), 1079-1088. https://doi.org/10.1016/S0301-4215(97)80002-5 
Wolsink, M. (2007). Planning of renewables schemes: Deliberative and fair decision-making on landscape issues instead of reproachful accusations of non-cooperation. Energy Policy 35 (5), 2692-2704. https://doi.org/10.1016/i.enpol.2006.12.002

Wolsink, M. (2010). Near-shore wind power-Protected seascapes, environmentalists' attitudes, and the technocratic planning perspective. Land Use Policy, 27, 195-203. https://doi.org/10.1016/i.landusepol.2009.04.004

Wolsink, M., \& van de Wardt, J.W. (1989). Visual Impact Assessment: a Review of Dutch Research. European Wind Energy Conference (EWEC), Glasgow, 471-475.

Ziegler, L., Gonzales, E., Rubert, T., Smolka, U., \& Melero, J.J. (2018). Lifetime extension of onshore wind turbines: A review covering Germany, Spain, Denmark, and the UK. Renewable and Sustainable Energy Reviews, 82, 2018, 1261-1271. https://doi.org/10.1016/j.rser.2017.09.100

Zieltra, D., \& Hocmair, H.H. (2011). Digital Street Data: free versus proprietary. GIM International, 25, 29-33.

Appendix 1(A1)

WPC

Wind energy penetration rate

WPC spatial penetration

\begin{tabular}{|c|c|c|c|c|c|}
\hline Country & MW & Country & $\%$ & Country & $\mathrm{KW} / \mathrm{Km}^{2}$ \\
\hline Germany & 56,132 & Denmark & 44.4 & Germany & 142 \\
\hline Spain & 23,170 & Portugal & 24.2 & Denmark & 130 \\
\hline United Kingdom & 18,872 & Ireland & 24.0 & Netherlands & 101 \\
\hline France & 13,759 & Germany & 20.8 & Belgium & 94 \\
\hline Italy & 9,479 & Spain & 18.6 & United Kingdom & 82 \\
\hline Denmark & 5,476 & United Kingdom & 13.5 & Portugal & 58 \\
\hline Portugal & 5,316 & Netherlands & 9.6 & Ireland & 48 \\
\hline Netherlands & 4,341 & Belgium & 6.0 & Spain & 46 \\
\hline Ireland & 3,127 & Italy & 5.2 & Italy & 32 \\
\hline Belgium & 2,843 & France & 4.8 & France & 25 \\
\hline
\end{tabular}

Table A1. The comparison about wind power capacity (WPC) (source: Fraile \& Mbistrova, 2018); for wind energy penetration rate (percentage of the average electricity demand covered by wind; source: Fraile \& Mbistrova, 2018) and for WPC spatial penetration (source: IEA, 2018) for all the ten countries examined.

The first five lines report the top five EU28 Countries for these variables. The following lines report the values of the considered variable (WPC, Wind energy penetration rate and WPC spatial penetration) in descending order for the remaining countries.

The WPC spatial penetration for France has been estimated using as reference for its spatial extension De Agostini, 2000. 